\title{
Sediments in Bottom-Arrested Gravity Plumes: Numerical Case Studies*
}

\author{
HERMANN FOHRMANN \\ Sonderforschungsbereich 313 der Universität Kiel, Kiel, Germany \\ JAN O. BACKHAUS \\ Institut für Meereskunde an der Universität Hamburg, Hamburg, Germany \\ Frank BlaUme AND Jan RUMOHR \\ Geomar Forschungszentrum für marine Geowissenschaften der Universität Kiel, Kiel, Germany
}

(Manuscript received 2 October 1996, in final form 2 February 1998)

\begin{abstract}
In the present paper a hydrostatic "reduced gravity" model, generally used to simulate transient bottomarrested gravity plumes, was coupled with a sediment transport model. The coupled model considers the respective contribution of suspended sediment particles on the buoyancy of a plume and allows one to simulate autosuspension and size-differential deposition of sediments based on the local turbulence and settling velocities. Simulations using the coupled model reveal that sediment-enriched plumes are able to inject both entrained and original shelf water masses into intermediate and bottom layers of an adjacent ocean basin in an ageostrophic dynamical balance. Hence the mechanism described here is more rapid than classic, "seawater" plumes, which are solely driven by surplus density of the water masses. Results suggest that "turbidity" plumes may constitute an important process in the formation and renewal of deep waters in the Arctic Ocean. In case a turbidity plume reaches its level of equilibrium density, deposition of suspended particles causes the density of the interstitial fluid to be lower than the density of the ambient fluid. This initiates upward convection within the water column.

The substantial difference between TS- and turbidity plumes is described by model experiments that utilize idealized slope and sediment distributions. A realistic simulation of a turbidity plume cascading down the continental slope of the western Barents Sea is presented. The computed distribution of deposited sediments agrees well with observations in an area of high accumulation of shelf-derived sediments. The frequency of occurrence of sediment-enriched gravity plumes originating from the Barents Sea shelf is estimated from the various geological variables (thickness of sediments at the bottom, grain size composition) measured from bottom sediments samples.
\end{abstract}

\section{Introduction}

With few exceptions at high latitudes intermediate and deep waters of the world's ocean are separated from direct contact with the atmosphere by a stable thermoor halocline. In the northern North Atlantic open ocean convection, in the Labrador and Greenland Seas (Gascard 1991; Rudels and Quadfasel 1991; Aagaard and Carmack 1994), accounts for ventilation and renewal of deep and intermediate water masses, forming a local driving force for the global "conveyer belt" circulation.

\footnotetext{
* Publication 341 of the Joint Research Program 313 of Kiel University (SFB 313).
}

Corresponding author address: Dr. Hermann Fohrmann, SFB313 der Universität Kiel, Heinrich-Hecht-Platz 10, D-24118 Kiel, Germany.

E-mail: hermann@sfb313.uni-kiel.de
In the permanently ice-covered Arctic Ocean, where a permanent halocline prevents open ocean convection, a renewal of subhalocline water masses is essentially driven by transport of dense shelf water masses into the deep basins at the continental margins (Fig. 1: Blindheim 1989; Schauer 1995; Jones et al. 1995).

These water masses are exported down the continental slope as dense bottom-arrested gravity plumes (Fig. 1: Aagaard 1989, Quadfasel et al. 1988; Jungclaus et al. 1995; Killworth 1983); their density excess is created during winter by both cooling and salt brine release during freezing of seawater (Rudels and Quadfasel 1991).

In tropical water, which are covered by a perennial thermocline, for example, in the Sulu Sea, oxygenation and renewal of deep waters has been attributed to the injection of a sediment-enriched gravity plume originating from the adjacent shelf (Quadfasel et al. 1990). After deposition of its sediment load the water of the plume caused a local negative density anomaly and ini- 

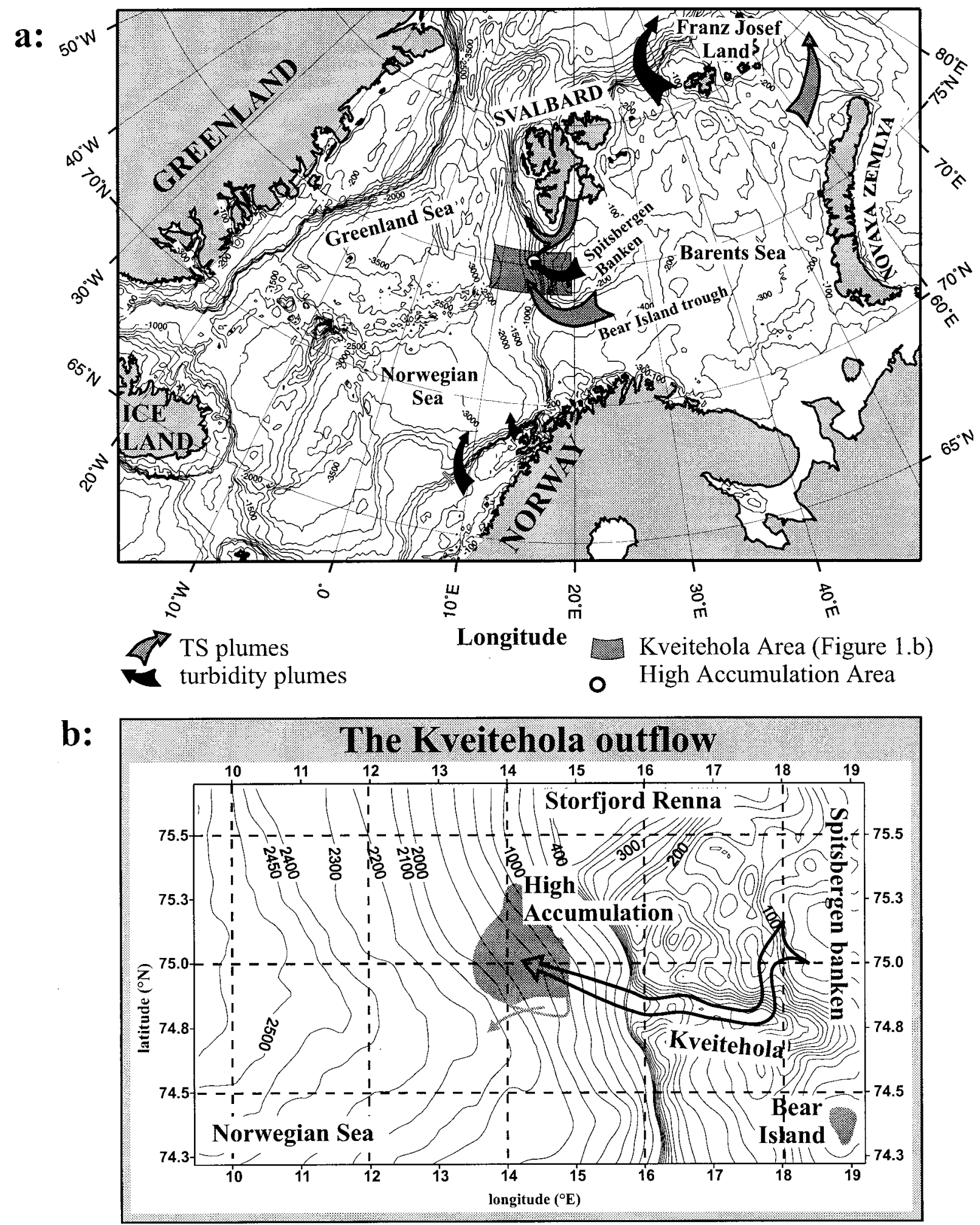

FIG. 1. Sites of TS plumes (gray) and turbidity plumes (black) in the northern North Atlantic and the Barents Sea (a). The pathways of the plumes are observed, postulated, or calculated as described in the text. The Kveitehola area in (b) extends from a water depth of $20 \mathrm{~m}$ at Spitsbergen Banken in the east down to $2500 \mathrm{~m}$ at the continental rise in the west. The arrow indicates the sedimentologically documented and simulated pathway from Spitsbergen Banken to the high accumulation area (HA). A southern part of the HA has moved down due to slope instability. 
tiated upward convection, resulting in a well-mixed and oxygenated water column with $T, S$ properties indicating a contribution of shelf waters. This finding was later supported by a laboratory experiment (Kerr 1991). Obviously, besides the negative buoyancy caused by cooling and phase changes of seawater, sediment particles (Allen 1994) may play an important role in slope convection and the resulting water-mass formation in plumes.

In the Arctic Ocean, in particular at the Eurasian shelves, there are quite a few sources for import of recent sediments into the ocean. The archipelagos of Svalbard, Franz Josef Land, and Novaya Zemlya (Fig. 1a) are partly covered by glaciers. Sediments abraised by glacial activity are released during the melting phase in summer (Pfirman and Solheim 1989). Indeed, some fjords in Svalbard reportedly attain a milky brown color in late June, which is a manifestation of substantial fine grained glacial sediment discharge (S. Semovski 1995, personal communication). Considerable amounts of sediment are released by the large Siberian rivers (Schlosser et al. 1995) and by the rivers along the North American coast. Schlosser estimated a fluvial sediment discharge to the Kara Sea released by the $\mathrm{Ob}$ and Jenissei Rivers to be in the order of 30 million tons per year. The Lena River with an annual freshwater discharge of 500 million $\mathrm{km}^{-3} \mathrm{a}^{-1}$ has corresponding sediment discharge in the order of 21 million $\mathrm{t}^{-1}$. The bulk of these sediments (83\%-90\%) accumulate in a vast delta plain and the import of sediments to the Laptev Sea, the key region for the transpolar drift, has been estimated in the range of 2.1-3.5 million $\mathrm{t} \mathrm{a}^{-1}$ (Alabyan et al. 1995). The ample supply of sediment to the shelves around the Arctic Ocean is partly exported with the transpolar drift, frozen within the ice. Wollenberg (1993) estimates transport of ice-bound sediments through Fram Strait to be in the order of 7 million $\mathrm{t}^{-1}$.

It appears to be also an export of shelf sediments into the deep adjacent ocean by means of slope convection, for instance, as has been observed in the Tropics. This export is not dependent on excess density caused by cooling and brine release, which at present is thought to be the principal mechanism responsible for initiation of slope convection in the Arctic Ocean (Aagaard et al. 1985; Killworth 1983). However, the contribution of turbidity plumes to water mass formation in the Arctic Ocean has not received adequate recognition and suitable observations are lacking in the literature. Therefore, in order to gain more insight into the role of sediments in Arctic slope convection, we present here a new sediment-enriched gravity plume model and results from a field study at the Barents Sea continental slope.

A site was chosen where the information about submarine topography and the regional Holocene sediment distribution (thickness and texture) was well established, and where the sedimentary record was not affected by ice-mediated transport. This model domain is located in the western Barents Sea and the adjacent continental slope (Fig. 1) where detailed sedimentological and oceanographical information is available. The investigation of cross-shelf sediment transport in the eastern Norwegian Sea has revealed several high accumulation areas of Holocene and Late Glacial (Termination I) age at the continental slope adjacent to large cross-shelf valleys. One of these sites is located seaward of the glacially generated submarine Kveitehola Valley (ca. 120 $\mathrm{km}$ long) at $75^{\circ} \mathrm{N}$. Its inner basin is connected to a system of channels draining parts of the Spitsbergen and Bear Island Banks. Analysis of sediment cores (40$75 \mathrm{~cm}$ long) from export areas, from transport pathways, and from deposition locations were carried out by means of the Atterberg method. In contrast to the debris flow, which is a common feature at the adjacent continental slope off Bear Island Trough (Fig. 1a), the well-preserved sediment layers of the high accumulation area off Kveitehola cover the continental slope with sediment up to four meters thick. The sediment mainly consists of homogeneous fine-grained silty muds $(80 \%<20 \mu \mathrm{m})$ with a minor content of sand-sized particles $(<5 \%>63$ $\mu \mathrm{m}$ ) (Core 23258; Blaume 1992). The center of the Holocene accumulation area, roughly $40 \mathrm{~km}$ in diameter, was observed in water depths of $1100 \mathrm{~m}$ to $1800 \mathrm{~m}$ at $75^{\circ} \mathrm{N}, 14^{\circ} \mathrm{E}$ where the sedimentation rates of the postglacial sediments (26-164 cm kyr ${ }^{-1}$ Core 23258; Blaume 1992) far exceed pelagic values known from the GIN Sea (Vogelsang 1990; Paetsch 1992).

For a better understanding and interpretation of the geological record, quasi-synoptic hydrographic surveys during typical summer and winter situations were carried out (Blaume 1992; Rumohr and Blaume 1996). CTD and transmissiometer measurements with high temporal and spatial resolution were used to study the regional distribution of water masses and nepheloid layers to investigate the processes responsible for high sediment accumulation on the continental slope.

Whereas in surface layers biogenic particles account for most of the transmission signal, resuspended and advected material dominates intermediate and near-bottom nepheloid layers (McCave 1984). In general, a midwater particulate minimum in the core of the North Atlantic Water (NAW) between 200 and $400 \mathrm{~m}$ water depth was noticeable in CTD profiles (Fig. 2). Below this, particle concentrations increased to maximum values of up to $7.05 \mathrm{mg} \mathrm{l}^{-1}$ (Thomsen 1993) in the bottom nepheloid layer (BNL), which was up to $200 \mathrm{~m}$ thick (Fig. $2 \mathrm{~b})$. Highest values $\left(>26 \% \mathrm{~m}^{-1}\right)$ were measured between 1300 and $1500 \mathrm{~m}$ water depth $\left(14^{\circ}-15^{\circ} \mathrm{N}\right)$. Here a BNL anomaly directly above the high accumulation area was mapped (Fig. 2b), where attenuation at $5 \mathrm{~m}$ above bottom was over a factor of 2 higher than in the midwater minimum (Fig. 3). Additionally, several intrusions of higher particle load were detected in the transition zone between NAW and Norwegian Sea Deep Water (NSDW) at the upper slope. Up to $200 \mathrm{~m}$ thick, these intermediate nepheloid layers (INLs) are strongly correlated with temperature and salinity inversions (Fig. 

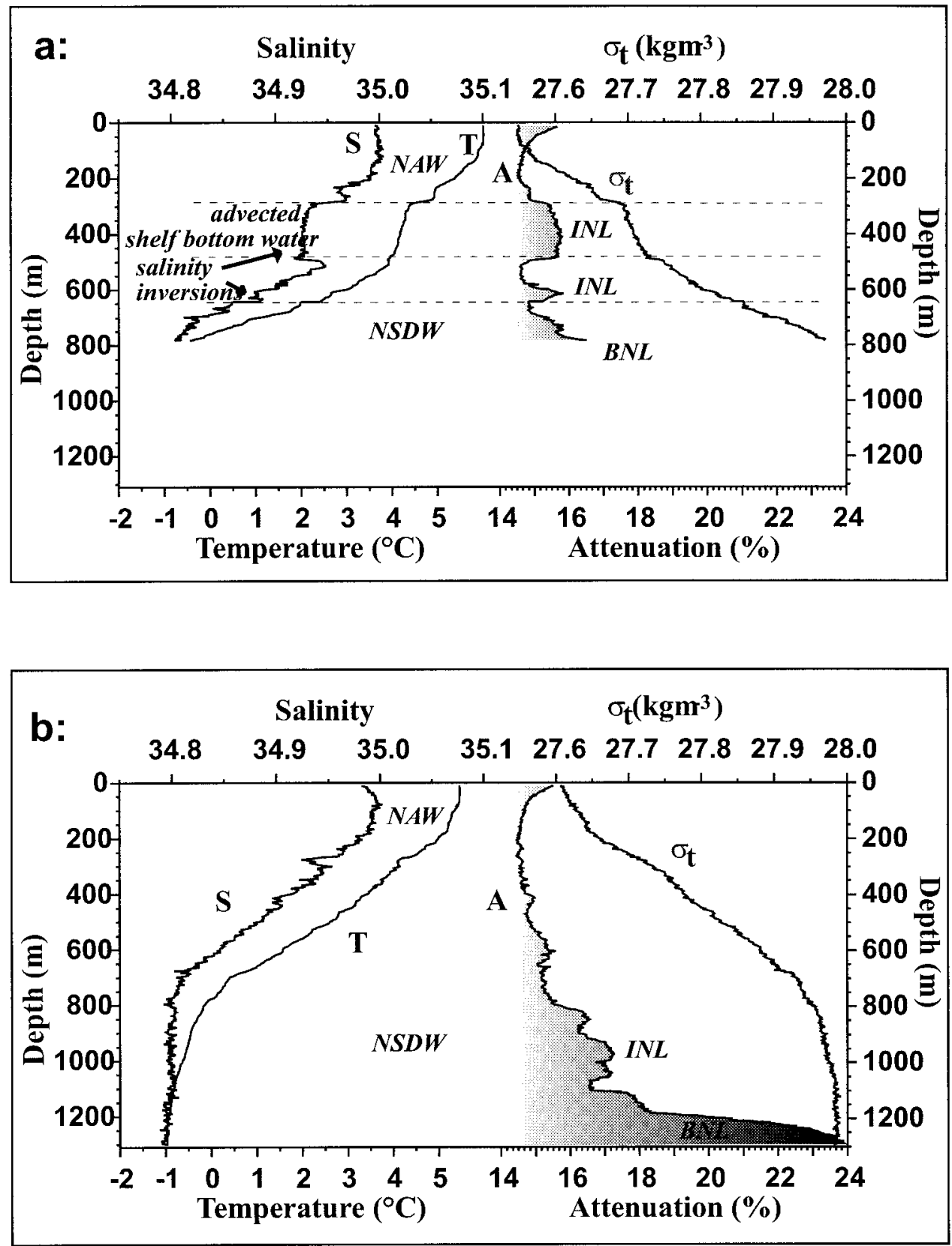

FIG. 2. CTD-attenuation casts during cruise Poseidon 181 in March 1991: (a) at the upper slope at a depth of $800 \mathrm{~m}$, and (b) above the high accumulation area at a depth of $1300 \mathrm{~m}$. At both stations the uppermost water column $(0-200 \mathrm{~m})$ represents warm and saline North Atlantic Water (NAW). Below $700 \mathrm{~m}$, cold and relatively fresh Norwegian Sea Deep Water (NSDW) was found. (a) Two salinity inversions, correlated with high attenuation values (high particle load), one between 300 and $500 \mathrm{~m}$ and the other centered around 650 $\mathrm{m}$. Both casts show high particle load in the BNL, with highest values at (b) above the accumulation area.

2a), indicating advection of shelf bottom water from the Kveitehola Valley (Blaume 1992). Both the BNLs and INLs showed strong spatial and temporal variability.

This combination of sedimentological and hydrographical data presents evidence that cold, particle-enriched shelf bottom water from Spitsbergen Bank flows through Kveitehola (guided by topography), penetrates the thermocline between NAW and NSDW, and descends into the deeper basin (Figs. 4 and 1b). Parts of the plume are detached from the bottom and carry their particle load into the intermediate water column. With decreasing slope inclination at a depth of $1400 \mathrm{~m}$, the plume decelerates and particle deposition takes place. This is indicated by the spatial distribution, orientation, 


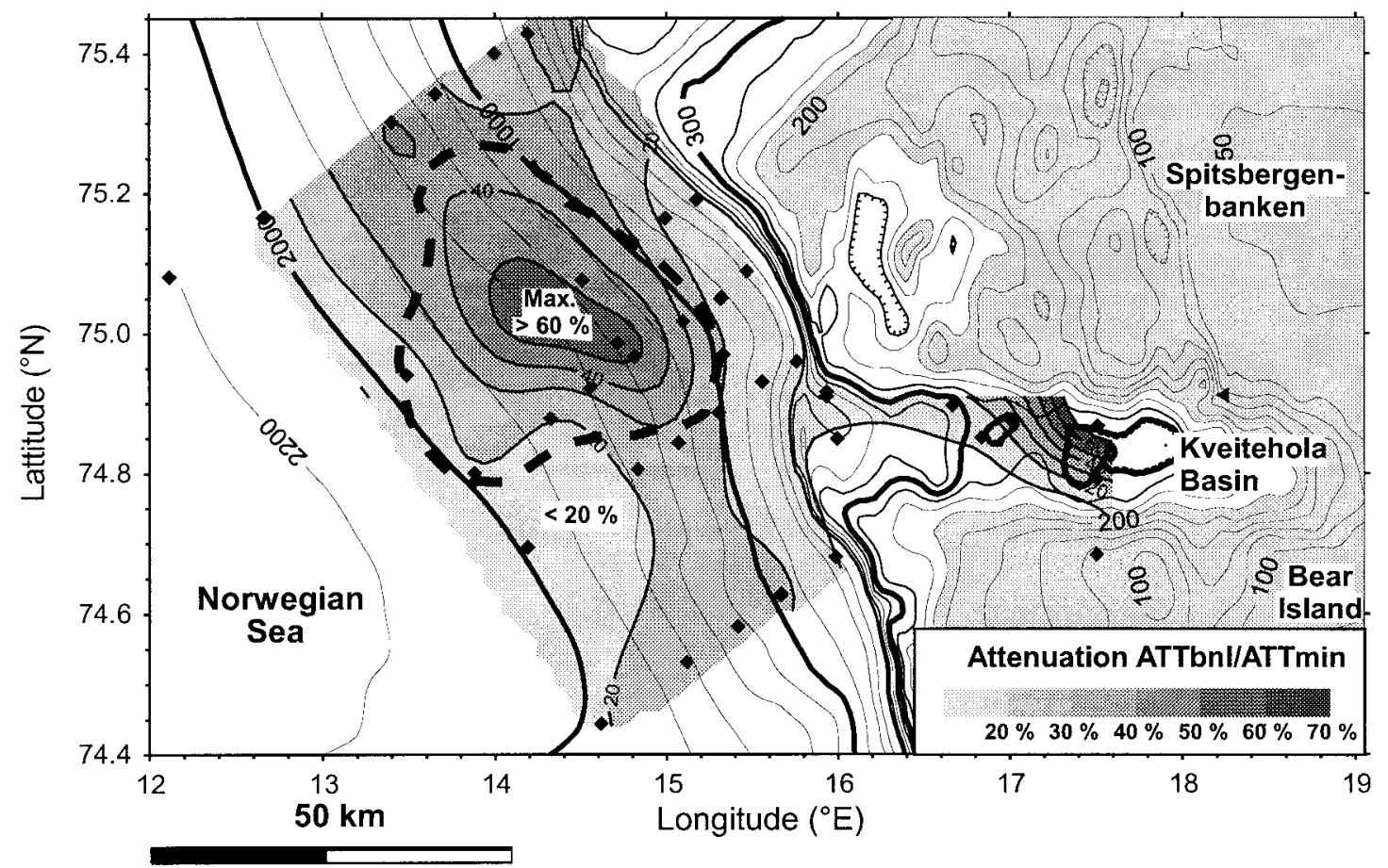

FIG. 3. Correlation of synoptic measurements to geological documentation. Attenuation data were obtained during Cruise Poseidon 181 (March 1991). In the high accumulation area (dashed contour) the thickness of holocene sediments is $>1 \mathrm{~m}$. Including sediments of termination I the maximum thickness is up to $8 \mathrm{~m}$. Gray shading indicates the relative attenuation at the bottom (attenuation in the BNL divided by the attenuation minimum in the water column) reaching from $20 \%$ (light gray) to $80 \%$ (dark gray).

and shape of the BNL anomaly just above the high accumulation area (Fig. 3). The high accumulation area is therefore interpreted as the geological record of channelized, topographically controlled low density turbidity plumes (Blaume 1992) and represents a case of sediment transport and slope convection through cascading bottom water derived from the western Barents Sea.

Depending on current velocity, grain size distribution, and suspended particle concentration, different types of turbidity plumes may occur. Following the classification of Stow (1994) the spectrum ranges from debris or mud flows with very high sediment concentrations $(C>500$ $\mathrm{g}^{-1}$ ) down to bottom-arrested currents with extremely low concentrations $\left(C<0.025 \mathrm{~g} \mathrm{l}^{-1}\right)$. Between these classes two different kinds of turbidity currents can occur, the high density turbidity currents with suspended particle concentrations in the range of 50-250 $\mathrm{g}^{-1}$ and low density turbidity currents (called "turbidity plumes" in the following) with suspended particle concentrations in the range of $0.025-3.0 \mathrm{~g} \mathrm{l}^{-1}$ (Table 1).

Variations in concentration, current velocity, and grain size distribution of suspended sediment yield a different energetic stage of turbidity currents that in turn is reflected in the typical shapes and internal structures of the geological features. High density turbidity currents (very often with a strong erosional character) carry a wide spectrum of grain sizes (including coarse sand and gravel) with high velocities into the deep basins, creating characteristically graded sequences analogous to the Bouma structural scheme for sandy turbidites (Bouma 1962). In contrast, due to a limited grain-size spectrum (silt and clay-sized material) low density flows produce monotonically, structurally homogenous fine grained turbidite sequences (Stow and Shanmugam 1980; Einsele 1992) and result in muddy and partly laminated sediments.

In pursuit of the main goal of this investigation an existing numerical reduced-gravity model for bottomarrested gravity plumes (Jungclaus and Backhaus 1994; Jungclaus et al. 1995) was extended to a model that simulates the dynamics and water masses within sediment-enriched plumes. The sediment transport model was interactively coupled to the plume model. It considers prognostic equations for different grain size classes of sediments. By means of idealized test cases that mimic typical conditions of Arctic shelves and slopes, the differences between turbidity plumes and "classic," that is, particle free, cold, and saline shelf bottom water plumes (called TS plumes in the following) are described. A simulation for the realistic case of Kveitehola near Bear Island (Fig. 1b) is compared with observed sediment deposition patterns in the area of high sediment accumulation described above. Potential areas and conditions for upward-directed convection initiated by a turbidity plume upon loss of its particle content will be shown. 


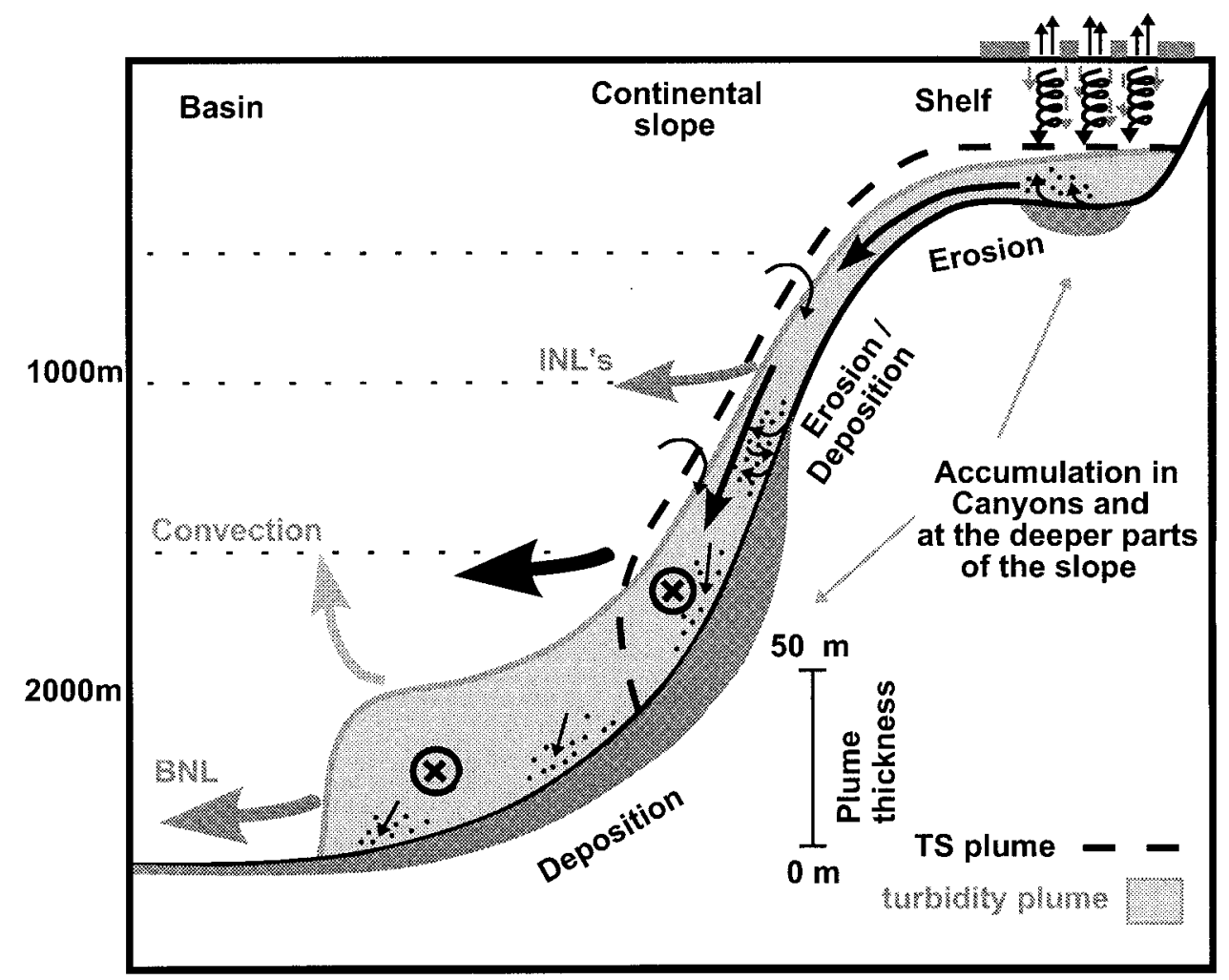

FIG. 4. Cartoon of shelf-slope convection. Due to cooling, freezing, and/or erosion of sediment dense bottom water is produced on the shallow shelves (at top on the right). As a TS plume (dashed) or a turbidity plume (light gray) the water cascades down the continental slope. Circles with crosses indicate flow into the plain. (Note different scales for plume thickness and water depth.)

\section{Turbidity plumes}

Turbidity plumes by virtue of their particle load are more energetic than pure TS plumes. Even comparatively low concentrations of suspended sediments can produce an increase in density that is large compared to the potential excess density of TS plumes. A volumetric concentration of $1 \mathrm{~g} \mathrm{l}^{-1}$ of suspended quartz particles, for example, yields an increase in density of 0.6 $\mathrm{kg} \mathrm{m}^{-3}$ (Table 1), corresponding to a salinity increase of 0.75. If the inclination of the slope is large enough the velocity of turbidity plumes may be much higher $\left(\geq 0.5-1.0 \mathrm{~m} \mathrm{~s}^{-1}\right)$ than those of pure TS plumes and, provided an erodable sediment layer is present, autosuspension can occur. Certainly an intensification of plume dynamics cannot persist for longer times (with the meaning of months or years). A loss of its sediment load on smoother slopes would decelerate the plume very rapidly. Further, if the density of the interstitial fluid becomes less than the density of the ambient water body, the plume attains positive buoyancy and initiates upward convection from the intrusion depth of the plume. As will be shown below the occurrence of such an instability depends on the initial conditions $(T-S$ characteristics and sediment load), on the rate of autosuspension and on the entrainment of ambient water, the later two depend in turn on the slope inclination, by the rate of turbulence within the plume.

Because of their limited spatial and temporal occurrence turbidity currents and especially low density currents, that is, turbidity plumes, are difficult to observe. Initial evidence of recent turbidity currents has been obtained from the destruction of submarine communication cables (Heezen and Ewing 1952; Menard 1964) or the movement of bottom deployed acoustic transponders (Garfield 1994). Investigations of sediments and water masses (Blaume 1992; Quadfasel et al. 1990) have shed some light on the nature of the less dense and less energetic turbidity plumes. The few available field observations have given impetus for a number of laboratory experiments (Carey et al. 1988; Laval et al. 1988; Kerr 1991). Sparks et al. (1993), Garcia and Parker (1993), and Bonnecaze et al. (1993, 1995) conducted several experiments on particle-enriched dense bottom currents with differing interstitial fluid densities and particle concentrations. These experiments demonstrate the increased buoyancy due to suspended particles, and they show how turbidity plumes spread at the bottom, size differentially deposit their particle load, and eventual lift up from the bottom and intrude at an internal interface. 
TABLE 1. Classification of suspension flows according to their suspended particulate matter concentrations, their excess density, and their equivalent salinity difference. Particle density was taken as density of quartz $\left(2651 \mathrm{~kg} \mathrm{~m}^{-3}\right)$. In the column at left different typical turbidity flow characteristics are specified as defined by Stow (1994). Examples for typical particle concentrations (Seston concentration): 1) Kveitehola area (5-10 m above bottom): $1-6 \mathrm{mg}^{-1}$ (Cruise Meteor 21-4); mid Norwegian continental slope (5-10 m above bottom): 0.15-1.5 mg 1-1 $^{-1}$ (Cruise Poseidon 205); Skagerrak (5-10 m above bottom): $0.5-2.25 \mathrm{mg} \mathrm{1}^{-1}$ (Cruise Poseidon 214); high accumulation area Bear Island: up to $5 \mathrm{mg} \mathrm{1}^{-1}$ (Thomsen 1993); Norwegian Sea Deep Water: at $75^{\circ} \mathrm{N}$ and $79^{\circ} \mathrm{N} 0.5-1 \mathrm{mg}^{-1}$ (R. Peinert 1996, personal communication); North East Water Polynya: intermediate water 1-2 mg 1 ${ }^{-1}$, BBL 2-3 $\mathrm{mg}^{-1}$ (Ritzrau 1998); Kiel Bight: about $2 \mathrm{mg}^{-1}$ at the surface $(0-5 \mathrm{~m})$ during phytoplankton bloom (R. Peinert 1996, personal communication), at the bottom (7-300 $\mathrm{cm}$ above) during winter 2-5 $\mathrm{mg} \mathrm{l}^{-1}$ (Ritzrau and Graf 1992). 2) Meltwater surface plumes: $25-500 \mathrm{mg} \mathrm{l}^{-1}$ (Pfirman and Solheim 1989). 3) The Amazon Outflow: $200 \mathrm{mg} \mathrm{l}^{-1}$ to $2 \mathrm{~g} \mathrm{l}^{-1}$ (Gibbs and Konwar 1986). 4) Suspension becomes visible; 5) viscous or plastic flows; no suspension flows.

\begin{tabular}{|c|c|c|c|}
\hline $\begin{array}{l}\text { Turbidity plume } \\
\text { character after } \\
\text { Stow (1994) }\end{array}$ & $\begin{array}{l}\text { Particu- } \\
\text { late } \\
\text { matter } \\
\text { concen- } \\
\text { tration } \\
\left(\mathrm{kg} \mathrm{m}^{-3}\right)\end{array}$ & $\begin{array}{l}\text { Excess } \\
\text { density } \\
\left(\mathrm{kg} \mathrm{m}^{-3}\right)\end{array}$ & $\begin{array}{l}\text { Equivalent } \\
\text { salinity } \\
\text { difference }\end{array}$ \\
\hline $\begin{array}{l}\text { Regular background } \\
\text { concentration near the } \\
\text { bottom }\end{array}$ & $0.001^{1}$ & 0.0000614 & 0.00076 \\
\hline Normal to low density & $0.025^{2}$ & 0.00153 & 0.019 \\
\hline Low density & $1.0^{2,3}$ & 0.6135 & 0.76 \\
\hline Low density & 3.0 & 1.8405 & 2.28 \\
\hline High density & $50.0^{4,5}$ & 30.675 & 38.0 \\
\hline High density to mud flow & $250.0^{5}$ & 153.375 & 180.0 \\
\hline
\end{tabular}

Different numerical experiments on sediment transport have been made. Parker et al. (1986) developed a turbulent closure model for the special case of a turbidity current in a submarine canyon. Adams (1981) and Sheng and Villaret (1989) investigated the effects and the distribution of particles in the BBL (bottom boundary layer). Other numerical simulations have been carried out to reproduce results of laboratory experiments. Bonnecaze et al. (1993, 1995) developed two-dimensional, vertically integrated layered models that show excellent agreement with laboratory observations. Dade and Huppert (1995a) presented a box model that predicts propagation and deposition from a two-dimensional particleenriched gravity plume on a horizontal surface, and their results agree well with experimental observations. However, all models have the disadvantage that they do not include the effects of topography.

\section{The coupled model}

\section{a. The hydrodynamic model}

Low-density turbidity plumes are almost Newtonian fluids and resemble turbulent pure water flows more than viscous or plastic flows. The latter would occur for sediment flows with concentrations in excess of $3 \mathrm{~g}^{-1}$ (Parker 1984). Particle concentrations considered in this investigation are well below that level. For this reason plume dynamics can be simulated with a modified primitive equation model for oceanographic purposes. The coupled model presented here combines a hydrostatic reduced-gravity plume model (Jungclaus and Backhaus 1994; Jungclaus et al. 1995) and an Eulerian sediment transport model that predicts the density modification due to the sediment load, erosion, deposition, and horizontal transport of suspended sediments (Fohrmann 1995 and 1996).

The principle structure of the model is illustrated in Fig. 5. The interface between the plume and an ambient water body can be visualized by a flexible membrane initially at rest on the seafloor. The plume is allowed to move freely below this membrane lifting it off the seabed. A movable lateral boundary, formed where the membrane leaves the seabed, enables the plume to find its own way on an arbitrary topography. This approach also allows the simulation of multiple interconnected plumes of arbitrary shape [for further details see Jungclaus and Backhaus (1994) and Fohrmann (1993)]. Prognostic equations are solved for temperature and salinity, velocity field, plume height, and for up to three grain size classes of sediment.

The transport is described by

$$
\mathbf{V}=(U, V)
$$

where $U$ and $V$ are calculated by integrating velocities $(u, v)$ over the height $(H)$ of the plume, respectively:

$$
U=\int_{H} u d z, \quad V=\int_{H} v d z .
$$

The averaged velocities are

$$
\bar{u}=U / H \text { and } \bar{v}=V / H \text {, with } H=D-\zeta \text {. }
$$

Vertical integration of the equations of motion yields to

$$
\begin{aligned}
& \frac{\partial U}{\partial t}+\boldsymbol{\nabla}\left[\mathbf{V} \frac{U}{H}-A_{H} H \nabla \frac{U}{H}\right]-f V \\
&=-g^{\prime} H \frac{\partial \zeta}{\partial x}-g \frac{H^{2}}{2 \bar{\rho}} \frac{\partial \rho}{\partial x}-\frac{\tau_{\text {bot } x}}{\bar{\rho}}+\frac{\tau_{\text {int } x}}{\bar{\rho}}, \\
& \frac{\partial V}{\partial t}+\nabla\left[\mathbf{V} \frac{V}{H}-A_{H} H \nabla \frac{V}{H}\right]+f U \\
&=-g^{\prime} H \frac{\partial \zeta}{\partial y}-g \frac{H^{2}}{2 \bar{\rho}} \frac{\partial \rho}{\partial y}-\frac{\tau_{\text {bot } y}}{\bar{\rho}}+\frac{\tau_{\text {int } y}}{\bar{\rho}},
\end{aligned}
$$

with the coefficient of horizontal turbulent exchange $\left(A_{H}\right.$ $\left.=100 \mathrm{~m}^{2} \mathrm{~s}^{-1}\right)$, Coriolis parameter $(f)$, and mean density $(\bar{\rho})$. Terms to the left of Eqs. (4) and (5) are from left to right the local rate of change with time, advection, turbulent diffusion, and the Coriolis term. To the right of Eqs. (4) and (5) is at first the barotropic pressure gradient, with

$$
g^{\prime}=g \frac{\rho_{\mathrm{Pl}}-\rho_{a}}{\bar{\rho}}
$$




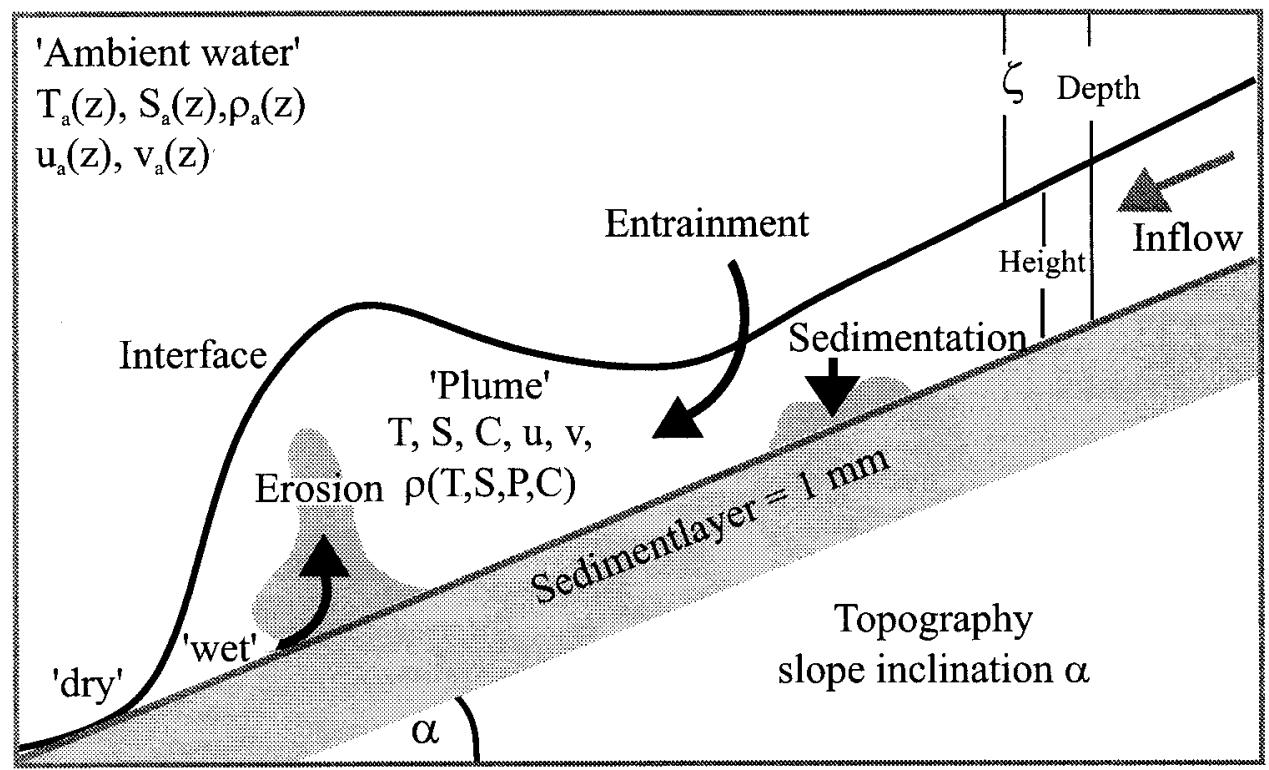

FIG. 5. Schematic structure of the model described in the text.

as "reduced gravity." Variables that correspond to ambient quantities are indicated by the subscript $a$, whereas those corresponding to quantities within the plume are indicated by the subscript Pl. The second term on the right-hand side is the baroclinic pressure gradient followed by the nonlinear bottom stress:

$$
\frac{\tau_{\text {bot }}}{\bar{\rho}}=r_{\text {bot }} \mathbf{v v}
$$

and, at last, the interface stress

$$
\frac{\tau_{\text {int }}}{\bar{\rho}}=r_{\text {int }}\left(\mathbf{v}_{a}-\mathbf{v}_{\mathrm{Pl}}\right) \sqrt{\left(\bar{u}_{a}-\bar{u}_{\mathrm{Pl}}\right)^{2}+\left(\overline{\boldsymbol{v}}_{a}-\bar{v}_{\mathrm{Pl}}\right)^{2}} .
$$

Since the ambient water body is dynamically inactive $\left(\overline{v_{a}}=0\right)$ according to the reduced-gravity concept, Eq. (8) reduces to

$$
\frac{\tau_{\text {int }}}{\bar{\rho}}=-r_{\text {int }} \bar{v}_{P l}\left|\mathbf{v}_{\mathrm{Pl}}\right| .
$$

The dimensionless friction coefficients have been determined in earlier experiments (Jungclaus and Backhaus 1994) and are set to $r_{\text {bot }}=3 \times 10^{-3}$ and $r_{\text {int }}=6$ $\times 10^{-4}$.

The interface between the plume and ambient water is semipermeable in that it only allows a transport of ambient water into the plume (Turner 1973), which is considered in the equation of continuity:

$$
\frac{\partial \zeta}{\partial t}+\frac{\partial U}{\partial x}+\frac{\partial V}{\partial y}=w_{e} .
$$

Following Jungclaus and Backhaus the entrainment of ambient water into the plume is calculated during the model simulation using the entrainment velocity $\mathrm{w}_{\mathrm{e}}$, which is defined as

$$
w_{e}=\frac{c_{l}^{2}}{S_{m}} \sqrt{\bar{u}^{2}+\bar{v}^{2}+\frac{g^{\prime} H}{S_{m}}},
$$

where $c_{1}$ is a proportionality constant $\left(c_{1}=0.027\right)$. The turbulent Smith number $(\mathrm{Sm})$, defined by Mellor and Durbin (1975) as

$$
\mathrm{Sm}=\frac{\mathrm{Ri}}{0.725\left(\mathrm{Ri}+0.186-\sqrt{\mathrm{Ri}^{2}-0.316 \mathrm{Ri}+0.0346}\right)},
$$

is a function of the Richardson number Ri $=g^{\prime} H /\left(\bar{u}^{2}\right.$ $\left.+\bar{v}^{2}\right)$.

The integrated equations for conservation of heat and salt are:

$\frac{\partial T}{d t}+\bar{u} \frac{\partial T}{\partial x}+\bar{v} \frac{\partial T}{\partial y}+w_{e} \frac{T_{P l}-T_{a}}{H}=\frac{A_{H t}}{H} \nabla(H \nabla T)$,

$\frac{\partial S}{d t}+\bar{u} \frac{\partial S}{\partial x}+\bar{v} \frac{\partial S}{\partial y}+w_{e} \frac{S_{P l}-S_{a}}{H}=\frac{A_{H s}}{H} \nabla(H \nabla S)$,

where $A_{H t}$ and $A_{H s}\left(25 \mathrm{~m}^{2} \mathrm{~s}^{-1}\right)$ are coefficients of horizontal turbulent diffusion. The fourth term to the left is the entrainment term, which depends on the difference of each quantity in the plume and the ambient water body. The model allows one to consider a vertical $T-S$ profile by allowing the plume to entrain different water masses down to depths. This $T-S$ differential entrainment affects both the $T-S$ properties and the dynamics of the plume, via a nonlinear equation of state [Eq. (15); UNESCO (1981)]:

$$
\rho_{w}=f(T, S, p) .
$$

More details about the model can be found in the papers by Jungclaus and Backhaus (1994) and Jungclaus et al. (1995). 
TABLE 2. Settling velocity calculated after Stokes, with $\nu$ from Jumars et al. (1993), $\rho_{w}$ after UNESCO (1981), $\rho_{s}=2651 \mathrm{~kg} \mathrm{~m}^{-3}, T=$ $0^{\circ} \mathrm{C}, S=35 \mathrm{psu}$, and $p=0$ dbar. The critical shear stress $\left(\tau^{*}\right)$ is taken from a bottom stress diagram (Unsöld 1984) and the critical mean velocity is calculated with $\rho_{\text {fluid }}=1030 \mathrm{~kg} \mathrm{~m}^{-3}$.

\begin{tabular}{|c|c|c|c|c|}
\hline & \multirow[b]{2}{*}{ Physical parameter } & & \multicolumn{2}{|c|}{ Grain size $d(\mu \mathrm{m})$} \\
\hline & & & 20 & 63 \\
\hline Settling velocity & Stokes & $w_{s}\left(\mathrm{~m} \mathrm{~s}^{-1}\right)$ & $1.93 \times 10^{-4}$ & $1.92 \times 10^{-3}$ \\
\hline Settling velocity & Stokes & $w_{s}\left(\mathrm{~m} \mathrm{~s}^{-1}\right)$ & 16.67 & 165.37 \\
\hline Critical bottom stress & Unsöld (1984) & $\tau^{*}\left(\mathrm{~N} \mathrm{~m}^{-2}\right)$ & 0.055 & 0.095 \\
\hline Critical bottom velocity & Unsöld (1984) & $\mathbf{V}_{\text {bot }}^{*}\left(\mathrm{~m} \mathrm{~s}^{-1}\right)$ & $7.31 \times 10^{-3}$ & $9.6 \times 10^{-3}$ \\
\hline Critical mean velocity & Numerical & $\mathbf{v}^{*}\left(\mathrm{~m} \mathrm{~s}^{-1}\right)$ & 0.13 & 0.18 \\
\hline
\end{tabular}

\section{b. The sediment model}

\section{1) GRAIN SIZE FRACTIONS}

The model considers separate prognostic equations for the transport of different grain size fractions. Considering that fine grained particles form aggregates in seawater (Eisma 1986; Johnson 1983), the assumption was made that particles $<20 \mu \mathrm{m}$ (clay and fine silt) behave like $20-\mu \mathrm{m}$ quartz spheres and particles 20-63 $\mu \mathrm{m}$ (medium to coarse silt) like $63-\mu \mathrm{m}$ spheres. Sandsize particles $(>63 \mu \mathrm{m})$ are excluded from the simulations because their settling velocities are too high to assume a semipermanent suspension for those particles. In the simulations presented below transport of medium silt $(20 \mu \mathrm{m})$ and coarse silt $(63 \mu \mathrm{m})$ is calculated. Nearly the same distribution for the small and medium silt fractions was found in the area of high Holocene sediment accumulation near Bear Island.

\section{2) The BULK Density}

Suspended particles need to be sufficiently fine grained to remain in suspension for periods longer than the model time step. The resulting increase in total or bulk density of a turbidity plume can be considered as being semipermanent. With this assumption the bulk density $\rho_{m}$ of the suspension, which is the main driving force of a plume, can be calculated from a simple volumetric relationship (Adams 1981; Sheng and Villaret 1989; Allen 1994; Dade and Huppert 1995a):

$$
\rho_{m}=\sigma C+\rho_{w}(1-C),
$$

where $\sigma$ is the density of suspended particles, $\rho_{w}$ the density of the interstitial (pure) water [Eq. (15)], and $C$ the dimensionless volumetric concentration of particles in the plume, normalized to the particle density. The density of quartz $\left(\sigma=2651 \mathrm{~kg} \mathrm{~m}^{-3}\right.$; Brauns and Chudoba 1964) is used in this model as a normal density for all fractions considered. Typical values for an increase in density due to sediment load are listed in Table 1. Concentrations in the table follow the classification suggested by Stow (1994).

\section{3) Settling velocity}

Settling velocity $\left(w_{s t}\right)$ is calculated according to Stokes law, which considers the dependence on diameter and density of particles and the density of the fluid:

$$
w_{s i}=\frac{1}{18} \frac{\sigma-\rho_{w}}{\eta} g d_{i}^{2},
$$

where $\rho_{w}$ [Eq. (15)] is the density of the interstitial water, $\sigma=2651 \mathrm{~kg} \mathrm{~m}^{-3}$ the sediment density, and $\eta=1.83048$ $\times 10^{-2} \mathrm{~cm}^{2} \mathrm{~s}^{-1}$ the kinematic viscosity of water (initial conditions are taken at $T=0^{\circ} \mathrm{C}$ and $S=35 \mathrm{psu}$ ), $g$ is the acceleration due to gravity, and $d_{i}$ the grain size diameter of a particle fraction. Settling velocities for the grain size fractions used in this investigation are given in Table 2.

\section{4) Sediment transport}

If the settling velocity of the suspended particles is less than the convective velocity, then particles behave like passive tracers. In that case, their distribution is nearly homogenous in the plume because of the turbulent convection (Prandtl et al. 1990; Martin and Nokes 1988). Following Prandtl et al. (1990) the convective velocity can be estimated as $v_{\text {conv }}=0.6 u^{*}$, where $u^{*}$ is friction velocity. Using the critical values of $u^{*}$ reported in Table $2, v_{\text {conv }}$ is $\sim 5 \times 10^{-4}$, one order of magnitude larger than settling velocities used here.

Sediment transport is highly influenced by particle concentration. For high concentrations of particles, sediment transport will be altered in the following way: First, hindered settling reduces the settling velocity; second, resuspension is reduced or does not occur (Martin and Nokes 1988); and third, the turbulence of the flow is dampened. In the latter case, the evolution of turbulent kinetic energy has to be calculated within the flow (Parker et al. 1986). In the present study particle concentrations are low (Table 1). Therefore transport equations for suspended sediment particles are similar to equations for conservation of heat (13) and salt (14):

$$
\begin{aligned}
& \frac{\partial C_{i}}{d t}+\bar{u} \frac{\partial C_{i}}{\partial x}+\bar{v} \frac{\partial C_{i}}{\partial y}+w_{e} \frac{C_{i}-C_{a_{i}}}{H}-\frac{A_{H m}}{H} \nabla\left(H \nabla C_{i}\right) \\
& =E_{i}-D_{i} .
\end{aligned}
$$


Different particle size fractions are indicated by the subscript $i$. The terms from left to right are the local rate of change with time, advection of particles along $\bar{u}$ and $\bar{v}$, entrainment of particles, and horizontal diffusion. For simplicity, in the ambient water the concentration of suspended particles $\left(C_{a i}\right)$ is zero. Additional terms on the right are erosion (a gain) and deposition (a loss). All the above equations are solved numerically explicit, with an upstream scheme for advection (Jungclaus 1994; Fohrmann 1993).

\section{5) EROSION AND DEPOSITION}

Several models have been developed to describe erosion, transport, and deposition of sediments (e.g., Ariathurai and Krone 1976; Stow and Bowen 1980; Odd 1988; Pantin 1991; Sparks et al. 1993; Garcia and Parker 1993; Bonnecaze et al. 1993, 1995; Dade and Huppert 1995a, b; Zeng and Lowe 1997). Models that solve conservation equations for flow mass, sediment mass, and momentum balance are probably best suited to describe turbidity currents for a wide range of particle concentrations and sizes (Parker et al. 1986). In the present paper we use only small particles $\left(D_{i}=20 \mu \mathrm{m}\right.$ and 63 $\mu \mathrm{m}$ ) with low settling velocities (Table 2) and low particle concentrations $\left(C_{i \max }=1 \mathrm{~g} \mathrm{l}^{-1}\right.$; Table 1$)$. Under these conditions, it is assumed that the particles are transported like passive tracers so that effects of particles on turbulence and on the settling behavior of particles are negligible.

Laboratory experiments on threshold flow conditions for incipient transport of fine-grained bed material (Unsöld 1984) revealed that particles are generally deposited, unless the bottom shear stress $\tau$ exceeds a critical value $\tau_{i}^{*}$ and creates erosion. This critical bottom shear stress is defined by $\tau_{i}^{*}=\rho \mathbf{v}_{i_{\text {bot }}}^{* 2}$, with the critical velocity $\mathbf{v}_{i \text { bot }}^{* 2}$ taken from laboratory experiments of Unsöld (Table 2 ). In the model the actual bottom stress $\tau=\rho \mathbf{v}_{\text {fric }}^{2}$ depends on the friction velocity:

$$
\mathbf{v}_{\text {fric }}=\sqrt{r \mathbf{v}^{2}},
$$

at the seabed, with $r=0.003$ and $\mathbf{v}$ as mean velocity. The used value of $r$ yielded good agreement of model results and observations of the Svalbard Outflow (Jungclaus et al. 1995). The erosion rate of a grain size class is calculated according to relation 20:

$$
\begin{aligned}
& E_{i}=\frac{C_{i \max }-C_{i}}{C_{i \max }} \cdot \frac{S_{i \text { bottom }}}{H} ; \quad \tau>\tau_{i}^{*} \text { and } \\
& E_{i}=0 ; \tau \leq \tau_{i}^{*} .
\end{aligned}
$$

The erosion rate $E_{i}$ is limited by the difference between the maximum particle concentration $\left(C_{i \max }\right)$ and the actual particle concentration $\left(C_{i}\right)$, and by the availability of particles at the bottom $\left(S_{\text {ibottom }}\right)$. The increase of particle concentration in the well-mixed flow is inversely proportional to the thickness of the flow $(H)$. The ranges of particle concentrations and diameters used here allow us to parameterize the erosion rate with this simple approach, which is in good agreement to the more complex closures. In Fig. 6a, particle concentrations calculated with the present parameterization are compared to those calculated with the sediment entrainment coefficient used by Zeng and Lowe (1997, see also Pantin 1991; Garcia and Parker 1993). In the equation for conservation of sediment mass Zeng and Lowe (1997) use a sink/source term that combines erosion and deposition. In order to compare both approaches, a one-dimensional simulation was run. The initial particle concentration is zero, the flow velocity increases from zero at the beginning to $2 \mathrm{~m} \mathrm{~s}^{-1}$ after $5.5 \mathrm{~h}$, and decreases again to zero at hour 11. Flow thickness is $1 \mathrm{~m}$. The defined boundary conditions $\left(C_{i \max }=1 \mathrm{~g} \mathrm{l}^{-1}\right.$ and $S_{i \text { bottom }}=1$ $\mathrm{mm})$ are valid for both experiments. In the accelerating stage on the left the particles are eroded rapidly. With both models the two fractions are eroded within minutes. Hence, for initial conditions used here the two approaches are comparable.

In the present model erosion is controlled by the critical mean velocity (v), which is determined from Eq. (19) by inserting values for critical bottom velocities for respective grain sizes $\left(\mathbf{v}_{\text {fric }}=\mathbf{v}_{\text {bot }}\right)$. When the first fraction erodes, turbidity flow is established resulting in higher velocities and the critical shear stress of the next fraction will thus be exceeded, soon after. This happens mainly within the head of a plume (Fig. 5), where the availability of sediment is higher than at the following parts of a plume, as will be shown later. The simulations are started with an initial layer of $1 \mathrm{~mm}$ thickness of erodable sediment for each calculated fraction.

Deposition rates basically depend on the settling velocity and on the concentration of suspended particles. Pantin (1991), for example, uses the mean particle concentration $(C)$ within the flow, whereas Garcia and Parker (1993) and Zeng and Lowe (1997) use particle concentrations near the bottom $\left(c_{b}\right)$. Other approaches use the mean particle concentration and the height of the current (Ariathurai and Krone 1976; Martin and Nokes 1988; Sparks et al. 1993; Bonnecaze et al. 1993, 1995; Dade and Huppert 1995b). Some approaches include also the probability for particles to settle on the seabed (Stow and Shanmugam 1980; Odd 1988). Laboratory investigations done with particles of diameter $0.21-0.5$ mm (Martin and Nokes 1988) show that resuspension of settled particles occurs only in the small size fraction. In the present investigation the particles are 10 times smaller than the particles used by Martin and Nokes. Therefore the deposition rate $D_{i}$ is calculated by Eq. (21):

$$
\begin{aligned}
& D_{i}=\frac{C_{i}}{H} w_{s i} P ; \quad \tau \leq \tau_{i}^{*} \quad \text { and } \\
& D_{i}=0 ; \tau>\tau_{i}^{*} .
\end{aligned}
$$

At lower velocities, if the bottom stress is less than the critical shear stress $\left(\tau<\tau_{i}^{*}\right)$, sediment will be deposited. 

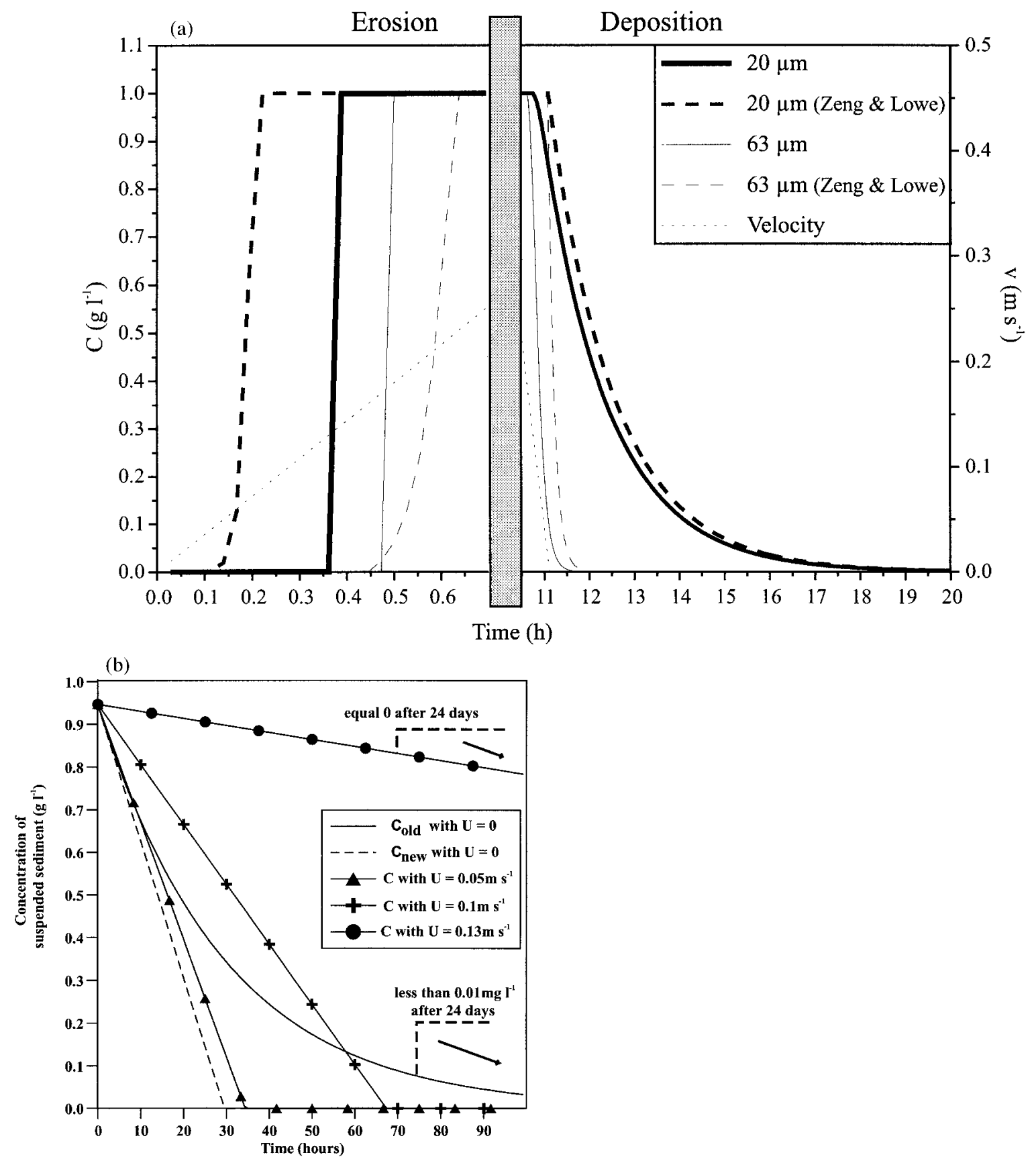

FIG. 6a. Concentration profiles for suspended sediment ( $C$ : see legend) and flow velocity $(v)$ vs time. On the left during the first 40-min particles are eroded. On the right between hour 10 and 20 particles are deposited again. Initial particle concentration is zero. Velocity increases from $0 \mathrm{~m} \mathrm{~s}^{-1}$ at $t=0 \mathrm{~h}$ to $2 \mathrm{~m} \mathrm{~s}^{-1}$ at $t=5.5 \mathrm{~h}$ and decreases again to $0 \mathrm{~m} \mathrm{~s}^{-1}$ at $t=11 \mathrm{~h}$.

Fig. 6b. Concentration profiles for suspended sediment $(C)$ vs time. The dashed line with dots is $C$ in quiescent water with plume height as settling distance. This line converges with zero and reaches small values $\left(C<0.01 \mathrm{mg} \mathrm{1^{-1 }}\right)$ after $573 \mathrm{~h}$. The solid line with stars is $C$ in quiescent water with the corrected settling distance. Other lines are concentration profiles with different current velocities.

The deposition rate is a function of the settling velocity $\left(w_{s i}\right)$, the concentration of suspended material $\left(C_{i}\right)$, and layer thickness $(H)$. The settling probability is given by:

$$
P=1-\frac{\tau}{\tau_{i}^{*}} .
$$

The probability $P$ includes the turbulence of the flow. The more turbulent the flow the greater the stress and the lower the probability of a particle remaining at the seabed. If $\tau_{i}$ is equal to or greater than the critical value, this term becomes zero or negative. In this case the probability of particle settling is zero. Numerical ex- 


\begin{tabular}{|c|c|}
\hline a.) GEOSTROPHIC & b.) 'NEAR-GEOSTROPHIC' \\
\hline Shell & Shelt $\quad$ Coriolis \\
\hline Coriolis & $500 \mathrm{~m}$ \\
\hline 1601mns $\overrightarrow{\vec{v}}$ & $1000 \mathrm{~m} \quad \vec{V}$ \\
\hline Solow & $1500 \times 12$ \\
\hline $\begin{array}{l}2000 \mathrm{n} \\
\text { Deep sea }\end{array}$ & $\begin{array}{l}2000 \mathrm{~m} \\
\text { Decpleat sea }\end{array}$ \\
\hline \multicolumn{2}{|c|}{ c.) FRICTION DOMINATED d.) } \\
\hline Shelf & Friction \\
\hline Coriolis & $\begin{array}{l}500 \mathrm{~m} \\
\quad \text { Coriolis }\end{array}$ \\
\hline $1006 \mathrm{ng}$ & $\beta \rightarrow 0^{\circ}$ \\
\hline 1500m $\quad \vec{v} \beta \beta_{\text {Pressure }}$ & $1500 \mathrm{~m}$ \\
\hline $\begin{array}{l}2600 \mathrm{~m} \\
\text { Deep } \sec \end{array}$ & $\begin{array}{l}2006 \text { m } \\
\text { Deep sea }\end{array}$ \\
\hline
\end{tabular}

FIG. 7. Cartoon of different equilibriae of forces acting on a plume on a sloping bottom.

periments with this equation in quiescent (nonturbulent) water (Atterberg experiment) yielded a much longer duration (twentyfold increase, Fig. 6b, solid line) of deposition than has been observed in the laboratory. The reason is that for every time step calculated with a constant layer thickness $\mathrm{H}$, the remaining particles will be spread over the entire water column. To solve this problem, at each time step the settling distance has been shortened by the distance the particles have settled during the previous time step (Fig. 6b, dashed line). The corrected distance is given by:

$$
H^{*}=H-w_{s i} \Delta t \cdot P,
$$

where $H$ is the layer thickness, $w_{s i}$ the settling velocity, $P$ the probability factor, and $\Delta t$ the time step. Concentration profiles (C vs time) for different mean current velocities are shown in Fig. 6b. Particle concentrations calculated with the present parameterization are compared to those calculated with the sediment entrainment coefficient used by Zeng and Lowe (1997). In the decelerating stage, on the right of Fig. 6a, the particles are deposited. The particle concentrations are nearly equal in both models, except at higher velocities, in which case the deposition rate is slightly lower in the present model.

\section{Idealized case studies}

With idealized case studies, dynamic differences between $T S$ plumes and turbidity plumes can be explained. Figure 7 shows four cases for the equilibrium of forces, based on (a) geostrophic balance only, (b) "near-geostrophic" balance (typical for TS plumes), and (c) and (d) friction dominated balance, which is typical for turbidity plumes, as will be shown below. In Fig. 7a the plume velocity is parallel to the isobaths. In Fig. 7b friction is added, which causes the plume to slow down and to change direction slightly downhill. From b to $d$ pressure gradient increases, leading to higher velocity and in turn to higher friction, advection, and entrainment. In Fig. 7 the entrainment force is added to the friction force, both processes force plumes to slow down. On the contrary, advection of momentum (nonlinearities) tends to accelerate the plume, again resulting in an increase of friction. Since friction grows faster, the angle between velocity and pressure $(\beta)$ decreases 


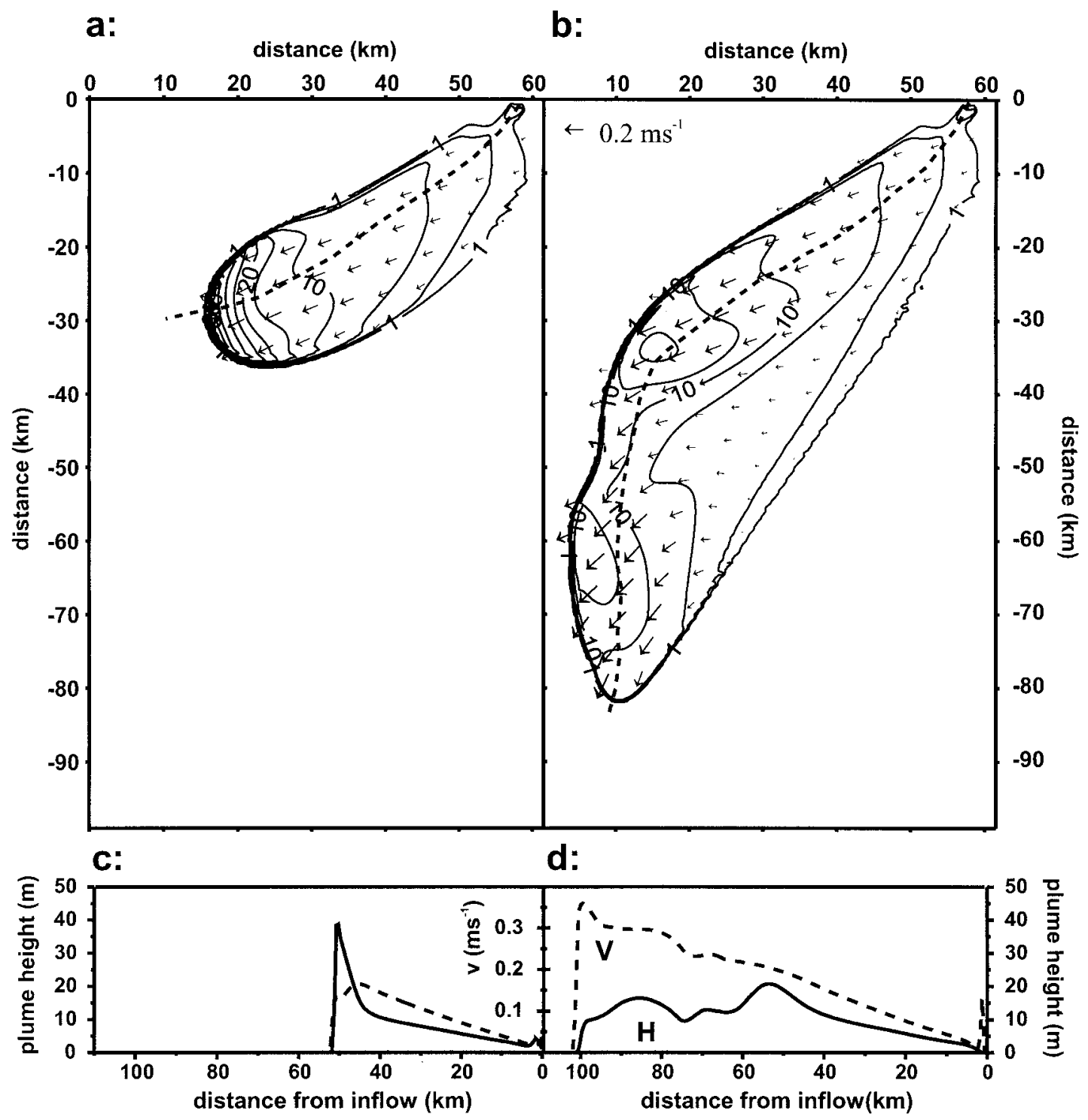

FIG. 8. Contour plots of plume heights (m) of a plume without (a) and with (b) suspended sediments after 3 days of simulation. Arrows indicate current speed and direction at representative grid points. (c) and (d) Regional distribution of height and velocity along the central axis (dashed lines in panels a and b).

as the pressure gradient increases. When friction dominates (Fig. $7 \mathrm{~d}$ ), $\beta$ may become $\approx 0$ and the plume velocity becomes almost perpendicular to the isobath.

\section{a. TS plume versus turbidity plume: A comparison}

The first experiment compares TS plumes with turbidity plumes. Figure 8 shows plume height on the third simulation day. Vectors illustrate magnitude and direction of the flow velocity. The slope is $1^{\circ}$ in the northsouth direction. The inflow is located at the northern boundary. Inflow temperature $\left(T_{\text {init }}=-1.8^{\circ} \mathrm{C}\right)$, salinity $\left(S_{\text {init }}=35.3 \mathrm{psu}\right)$, height $\left(H_{\text {init }}=20 \mathrm{~m}\right)$, and velocity $\left(v_{\text {init }}=0.1 \mathrm{~m} \mathrm{~s}^{-1}\right)$ were fixed for the duration of the inflow, which lasted for 1 day (Table 3). Therefore the amount of inflowing particle-free water is the same in both experiments. The ambient water is homogenous.

The TS plume simulation was run on a topography without sediment (Fig. 8a). Once entering the model domain, the TS plume accelerates and moves across the isobaths, being influenced mostly by friction. On its way it entrains ambient water. With decreasing density contrast the TS plume slows down. Gravity and entrainment of ambient water are thus two counteracting forcings. At a depth of about $500 \mathrm{~m}$ below the inflow, the Coriolis force dominates over friction. The equilibrium of forces changes from friction dominated to near geostrophic. With a small angle to the isobaths the plume descends slowly.

The turbidity plume simulation (Fig. 8b) differs from 


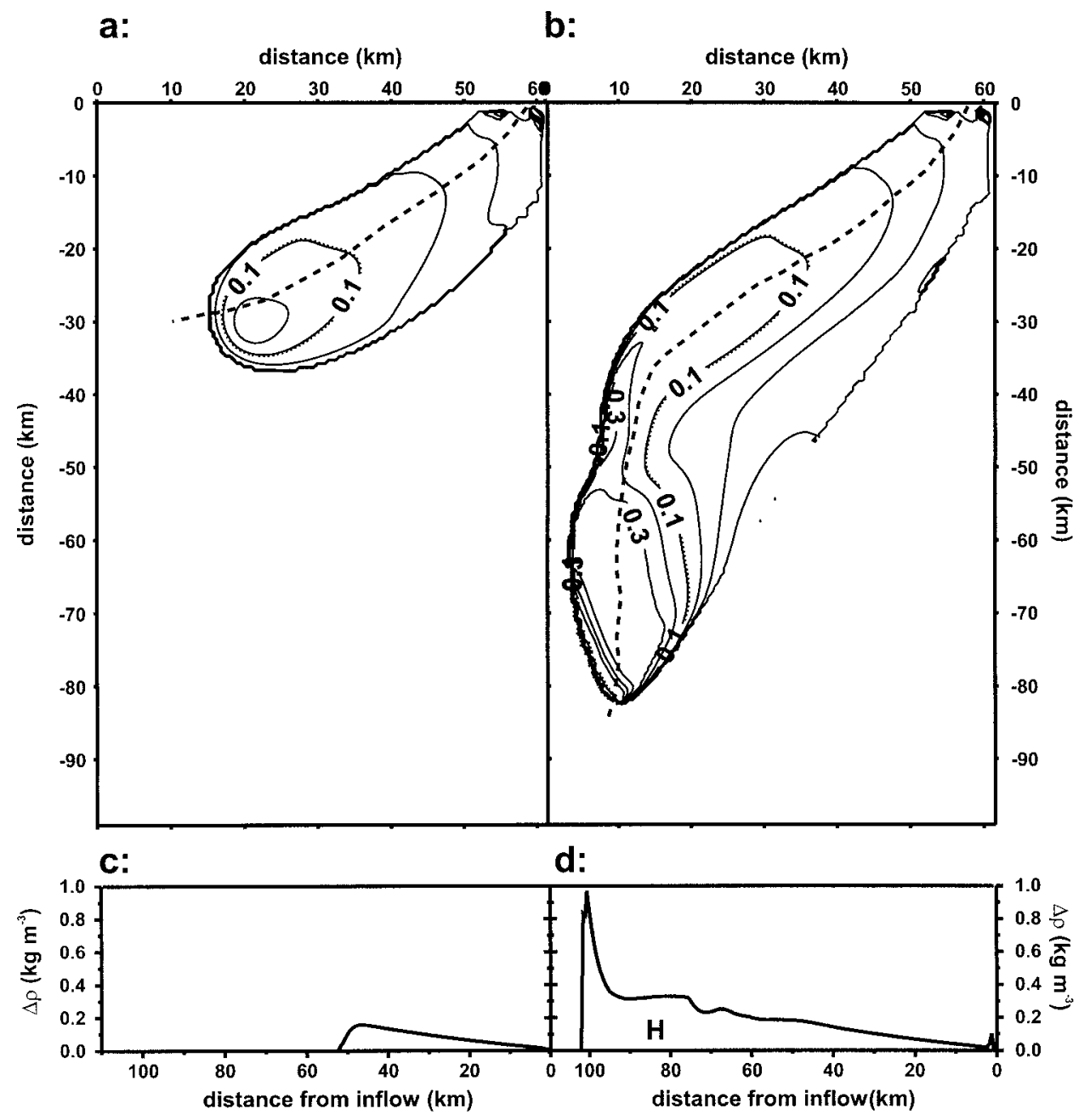

FIG. 9. Contour plots of density contrast $\Delta \rho\left(\mathrm{kg} \mathrm{m}^{-3}\right)$ of a plume without (a) and with (b) suspended sediments after 3 days of simulation. (c) and (d) Regional distribution of $\Delta \rho$ along the central axis (dashed lines in Figs. 8a and 8b).

the TS plume (Fig. 8a) due to the presence of an initial layer $(1 \mathrm{~mm}, 50 \% 20 \mu \mathrm{m}$ and $50 \% 63 \mu \mathrm{m})$ of sediment at the seabed. Near the inflow, the behavior of the turbidity plume is very similar to the $T S$ plume.

Farther down, above a critical velocity, erosion of sediments results in a density increase that accelerates the plume. This process continues as long as erodable sediment is available. Due to the strong acceleration of the plume, friction and advection increasingly dominate the simulation and the influence of Coriolis is reduced. Ultimately Coriolis becomes negligible and the resulting motion is almost completely perpendicular to the depth contours (Figs. 7c,d). The turbidity plume now descends faster $\left(v=0.36 \mathrm{~m} \mathrm{~s}^{-1}\right)$ and becomes thinner $(H=20$ m, Fig. 8d) than the TS plume $\left(v=0.17 \mathrm{~m} \mathrm{~s}^{-1}, H=\right.$ $40 \mathrm{~m}$, Fig. 8c).

Differences in the density contrast (Fig. 9) between plumes and ambient water result in different dynamical behavior. In both experiments the initial density contrast was set to $0.57 \mathrm{~kg} \mathrm{~m}^{-3}$. In the $T S$ plume the density contrast due to entrainment of ambient water decreases to $0.17 \mathrm{~kg} \mathrm{~m}^{-3}$ (Fig. 9c). The turbidity plume (Fig. 9b), by eroding bottom sediments predominantly near its head, shows an increasing density contrast up to about $1 \mathrm{~kg} \mathrm{~m}^{-3}$ (Fig. 9d). No erodable sediment is left behind for the "tail" of the turbidity plume (Figs. 10f,h), which leads to similar results on the upper part of the slope in both experiments.

After 3 days the water entrainment velocities of the tails of the plumes are much the same and close to zero in both experiments. Significant differences are evident at the head only. In the TS plume (Figs. 10a,d) the entrainment velocities reach values up to $0.10 \mathrm{~mm} \mathrm{~s}^{-1}$ in the head, whereas in the turbidity plume (Figs. 10b,e) they reach values of $0.24 \mathrm{~mm} \mathrm{~s}^{-1}$ in the head dropping to $0.17 \mathrm{~mm} \mathrm{~s}^{-1}$ behind the head. Excess density (Fig. 9 ) in the turbidity plume is higher than in the TS plume, although entrainment rate of ambient water is two times 

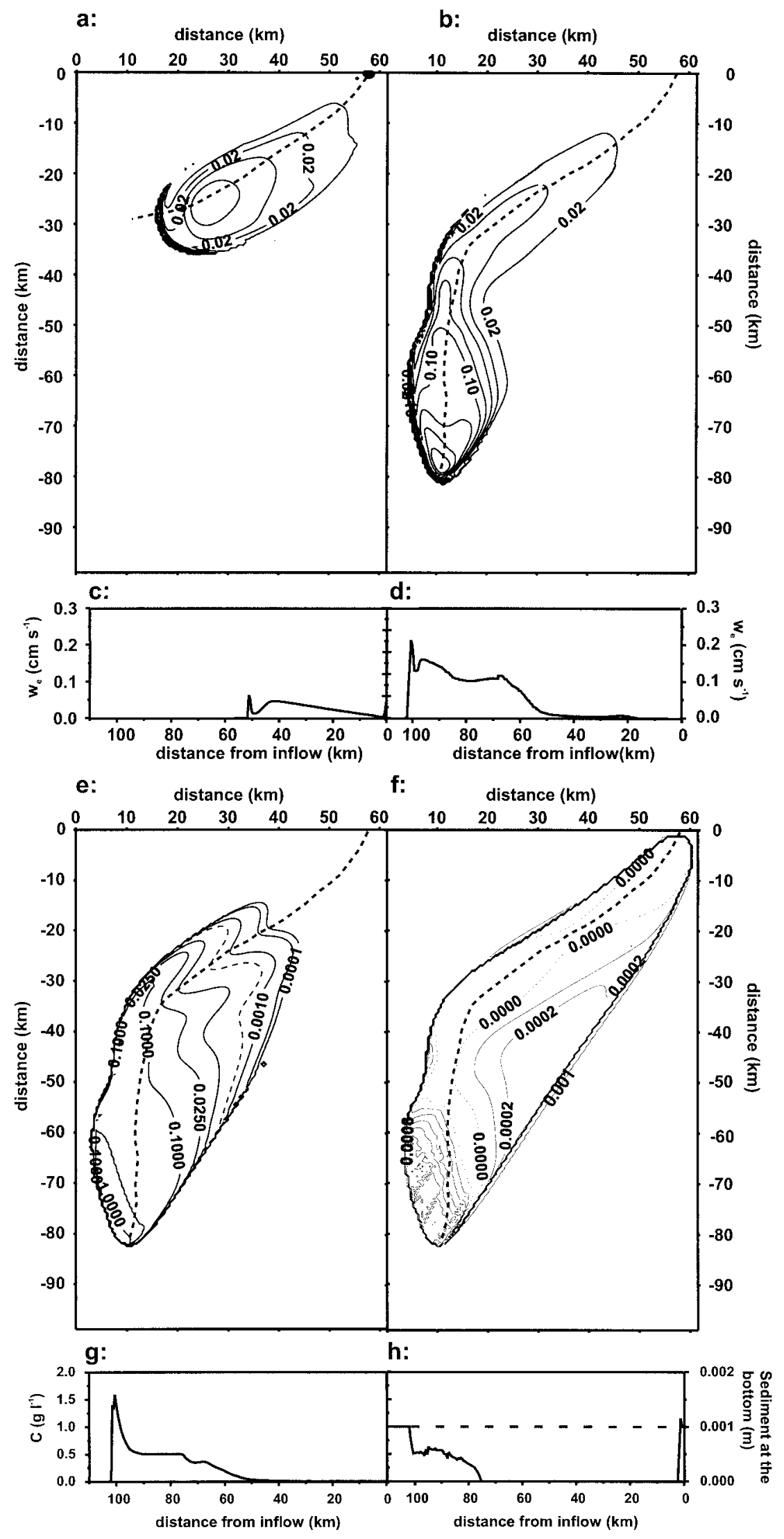
TABLE 3. Initial and boundary conditions as an overview.

\begin{tabular}{lcccccccccc}
\hline \hline & $\begin{array}{c}\text { Slope } \\
\alpha\left({ }^{\circ}\right)\end{array}$ & $\begin{array}{c}\text { Inflow } \\
\text { duration }\end{array}$ & $\begin{array}{c}T_{\text {inflow }} \\
\left({ }^{\circ} \mathrm{C}\right)\end{array}$ & $S_{\text {inflow }}$ & $\begin{array}{c}C_{\text {inflow }}\left(\mathrm{g} \mathrm{L}^{-1}\right) \\
\mathrm{i} \mathrm{s}^{-1}\end{array}$ & $\begin{array}{c}V_{\text {inflow }} \\
\mathrm{m}\end{array}$ & $\begin{array}{c}C_{\text {bottom }} \\
\mathrm{mm}\end{array}$ & $\begin{array}{c}T_{\text {ambient }} \\
\left({ }^{\circ} \mathrm{C}\right)\end{array}$ & $\begin{array}{c}S_{\text {ambient }} \\
(\mathrm{psu})\end{array}$ \\
\hline Figs. 8a, b & 1 & 1 day & -1.8 & 35.3 & 0.0 & 0.1 & 20 & 0 or 1 & -1.0 & 34.9 \\
Fig. 11 & 1 & 1 day & -1.8 & 35.3 & 0.0 & 0.1 & 20 & 0 or 1 & $0 / 2 /-1$ & $34.85 / 35.1 / 34.9$ \\
\hline
\end{tabular}

higher for the turbidity also. Isolines of the distribution of suspended particles $\left(\mathrm{g}^{-1}\right)$ of the turbidity plume (Fig. 10c) provide an explanation. There are very high values in the head corresponding to a particle load of more than $1.5 \mathrm{~g} \mathrm{l}^{-1}$ (Fig. 10f) and lower values in the upper part of the plume. The contour lines are similar to the density contours seen before.

This demonstrates that the suspended particle load is the decisive factor forcing the turbidity plume to sink to greater depth. The dashed contour represents a particle load of $25 \mathrm{mg} \mathrm{l}^{-1}$. This value lies between observed concentrations in the BNL and those in low density turbidity plumes (Table 1).

Quantitative criteria used to distinguish the different flows can be given by a few dimensionless numbers (Table 4). The Burger number

$$
B=\frac{\frac{g}{\bar{\rho}} \frac{\partial \bar{\rho}}{\partial z} H_{o}^{2}}{f_{o}^{2} L^{2}}
$$

is the ratio of gravity over Coriolis. The Rossby number Ro $=U(f L)^{-1}$ is the ratio of inertia over Coriolis. The Ekman number Ek $=A_{z}\left(\mathrm{fH}^{2}\right)^{-1}$ is the ratio of friction over Coriolis.

The numbers listed in Table 4, were calculated with typical values and are three times higher for the turbidity plume than for the TS plume. This points out that gravity, inertia, and friction are three times more important for the turbidity plume than for the TS plume.

In summary, turbidity plumes descend ageostrophically (dominated by gravity, friction, and inertia) and perpendicular to the slope since any possible decrease of the density difference due to entrainment of ambient water is overridden by an increase of the density difference due to sediment erosion.

\section{b. Water mass formation}

Especially at high latitudes, gravity plumes are involved in deep-water formation. As described above, turbidity plumes have higher densities amplifying their almost perpendicular to the isobaths directed gravity component. Turbidity plumes can thus descend faster and deeper into the deep sea and, by carrying and mod- ifying temperature and salinity characteristics, they produce distinct deep water masses. This is demonstrated in the $T-S$ diagram shown in Fig. 11.

For this simulation with reference to Jungclaus et al. (1995), the initial surrounding water mass is vertically structured with $T S$ distribution adjusted to typical shelf and slope conditions near Svalbard. The boundary and initial conditions are the same as in the experiments above $\left(H_{\text {init }}=20 \mathrm{~m}, v_{\text {init }}=0.1 \mathrm{~m} \mathrm{~s}^{-1}\right.$, Figs $8-10$, Table 3). In Fig. 11 results after three simulation days are shown, with gray crosses indicating the $T S$ plume and black dots indicating the development of the turbidity plume. On its way down the TS plume (gray arrows), originally consisting of cold and saline shelf bottom water $\left(T=-1.8^{\circ} \mathrm{C}, S=35.3 \mathrm{psu}\right)$, first entrains less saline ( $\mathrm{S}=34.85 \mathrm{psu}$ ) East Spitsbergen Water (ESW) with a temperature of $0^{\circ} \mathrm{C}$. Later, at a depth between 200 and $700 \mathrm{~m}$, the plume meets and entrains NAW ( $T$ $=2^{\circ} \mathrm{C}, S=35.1 \mathrm{psu}$ ). In this simulation the $T S$ plume does not reach the depth of the NSDW. In contrast the turbidity plume (gray and black arrows) crossing ESW and NAW sinks deep enough to reach the NSDW ( $T=$ $\left.-1^{\circ} \mathrm{C}, S=34.9 \mathrm{psu}\right)$. Obviously, after 3 days a turbidity plume reaches the NSDW; a TS plume does not.

We thus demonstrate that particle-enriched plumes can inject shelf water masses directly into deep layers of the ocean and produce deep water almost instantaneously, whereas TS plumes are slower, if they reach the deep sea at all. Compared with the simulation of the Svalbard Outflow, where it took 40 days for the TS plume to descend from the shelf edge down to $2500-\mathrm{m}$ water depth (Jungclaus et al. 1975), turbidity plumes are 10 times faster.

\section{c. Patchiness of sediment at the bottom}

Sediment patchiness at the bottom can strongly influence turbidity plumes. The plume may be separated into different parts: a near-geostrophic main body and ageostrophic offspins. This is demonstrated by an academic test case in which the initial condition differs from previous experiments by a prescribed sediment patchiness on the slope and by a constant inflow during the whole simulation time (3 days). Every $10 \mathrm{~km}$ there

FIG. 10. Contour plots of (water-) entrainment velocity $\mathrm{w}_{\mathrm{e}}\left(\mathrm{m} \mathrm{s}^{-1}\right)$ of a plume without (a) and with (b) suspended sediments and of a concentration $C\left(\mathrm{~g}^{-1}\right)$ of suspended particles (c) after 3 days of simulation. Regional distribution of $\mathrm{w}_{\mathrm{e}}(\mathrm{d})$ and (e) and of $C$ along the central axis (f) (central axis as dashed lines in Figs. 8a and 8b). 
TABLE 4. Dimensionless numbers calculated for the $T S$ and turbidity plume shown in Fig. 8.

\begin{tabular}{lccl}
\hline \hline & TS plume & $\begin{array}{c}\text { Turbidity } \\
\text { plume }\end{array}$ & \multicolumn{1}{c}{ Ratio } \\
\hline Burger number & 0.01 & 0.03 & Gravity/Coriolis \\
Rossby number & 0.1 & 0.3 & Inertia/Coriolis \\
Ekman number & 0.005 & 0.01 & Friction/Coriolis \\
\hline
\end{tabular}

is a region of sediment $2.5 \mathrm{~km}$ wide and $1 \mathrm{~mm}$ thick oriented perpendicular to the slope. The ambient water is not stratified. The objective of this idealized setup is to demonstrate the ability of a plume to split in different energetic parts. Nevertheless, constant inflow situations can occur during winter (e.g., the Svalbard Outflow), and narrow bands of sediment remind one of levees.

Contours in Fig. 12a denote plume height. Initially the plume behaves like a TS plume, as shown in Fig. 8a. But as the plume encounters the first sediment patch, the plume erodes sediment and the head of the plume cascades "drop shaped" ageostrophically down the continental slope, guided by the sediment patches at the bottom. The following plume water continues flowing across the first sediment patch behaving in a near-geostrophic way. Later it hits the next sediment patch and again the head descends. This process is repeated as often as sediment patches are encountered. The drops differ in place and time, the youngest at the left, becoming older from left to right (Fig. 12a). The drops are narrow and in contrast to the $T S$ plumes, which have a thick head and a shallow tail, the drops have a shallow head and a thick tail, in this case about $10 \mathrm{~m}$ in the head and about $30 \mathrm{~m}$ behind the head. This shape is a result of the dynamics of the drops. Figure $12 \mathrm{~b}$ shows the resulting velocity field. The contour lines represent the magnitude of the flow velocity. At the upper part, the plume descends near-geostrophically with velocities of about $0.2 \mathrm{~m} \mathrm{~s}^{-1}$. The drops are dynamically separated from the rest of the plume and they descend rapidly in an ageostrophical way, with instantaneous velocities of

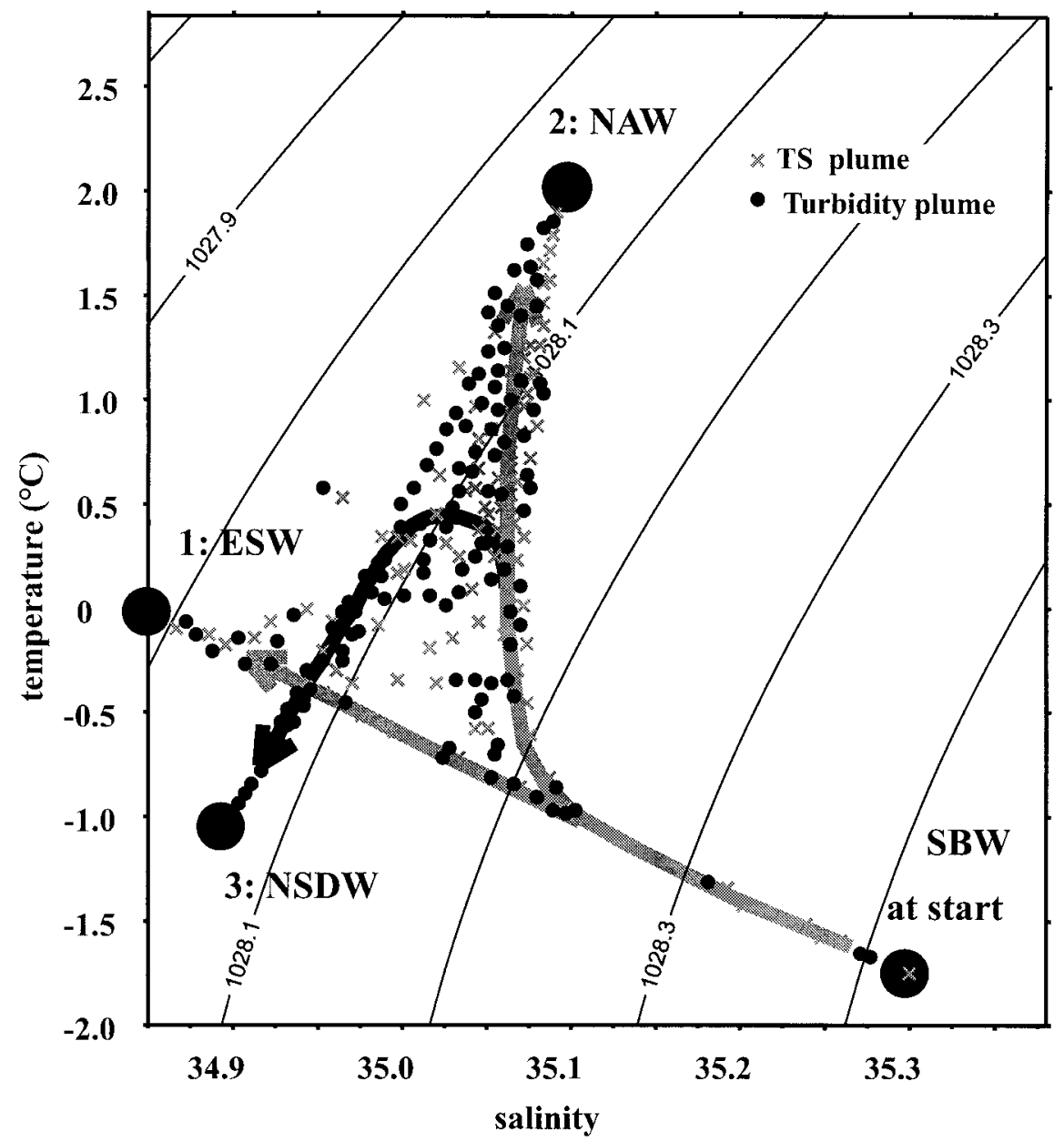

FIG. 11. Computed $T-S$ characteristics of plumes after 3 days, with particles (black dots) and without particles (gray crosses). Arrows indicate the different histories of their development. SBW: shelf bottom water, ESW: East Spitsbergen Water, NAW: North Atlantic Water, NSDW: Norwegian Sea Deep Water. 

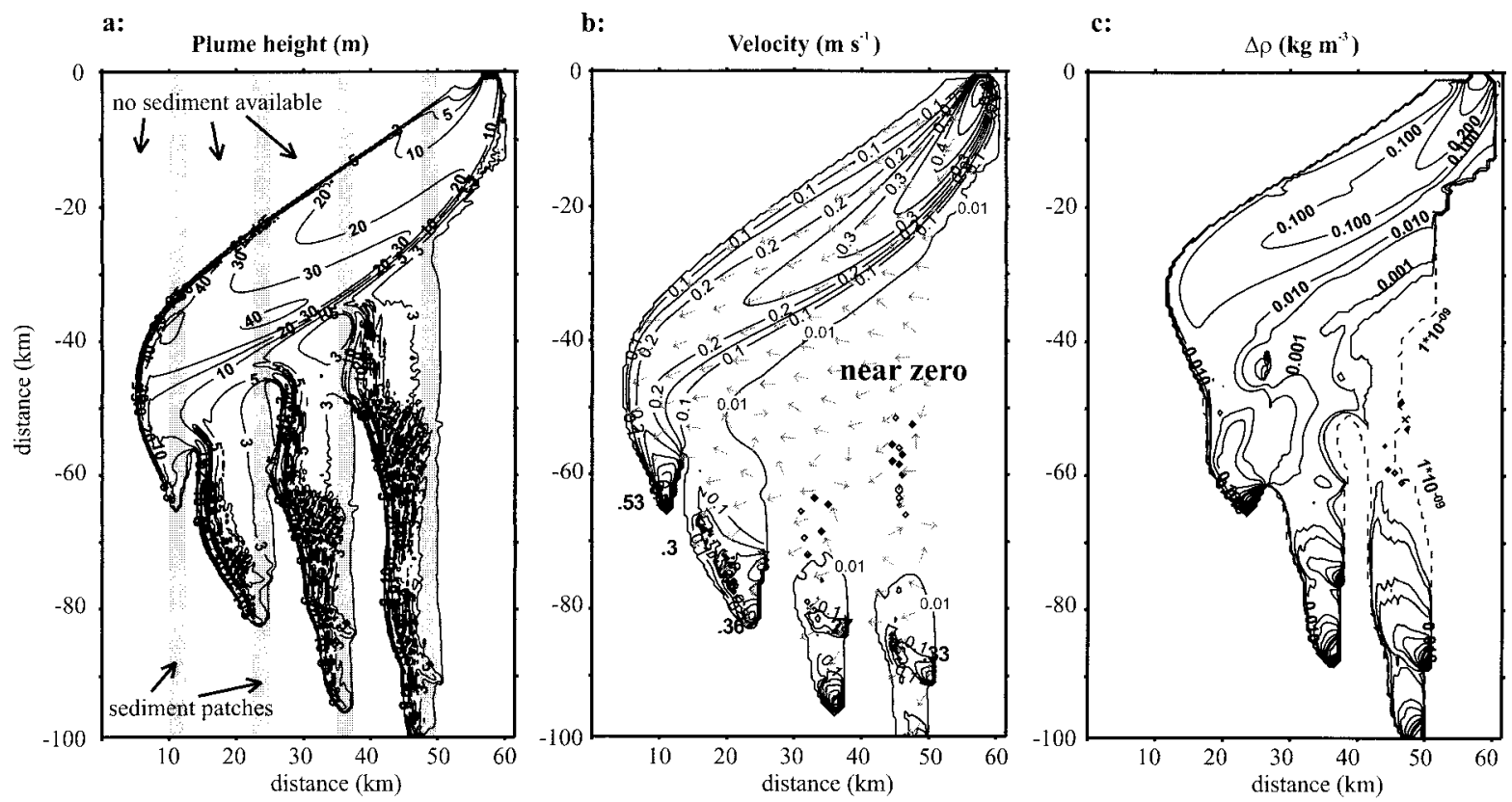

FIG. 12. Contour plots of plume height (a), velocity (b), and density contrast (c) after 3 days of simulation. Arrows at representative grid points indicate flow direction only. The topography is provided with patches of available sediment at the bottom (a) (gray stripes). Inclination of the bottom is $2^{\circ}$. Initially the flow is particle free.

about $0.4 \mathrm{~m} \mathrm{~s}^{-1}$, into the deeper basin. The areas above the drops are much less energetic with velocities below $0.05 \mathrm{~m} \mathrm{~s}^{-1}$ and differently directed, even flowing partly uphill. The density contrast is close to zero and inertia dominates the acting forces. Because of homogenous ambient water masses the density contrast cannot drop below zero (Fig. 12c) according to the hydrostatic approximation. The areas behind the drops can be visualized as clouds of dust behind fast cars driving through a desert.

\section{The Kveitehola Outflow}

To validate the coupled model a dense water outflow along the Kveitehola glacial cross-shelf valley was simulated. The model domain and topography are shown in Fig. 1b. To obtain accurate topographical data for the numerical grid, a compilation of a detailed bathymetric chart of the western Barents Sea (Norsk Polarinstitutt 1989) and high-resolution $3.5-\mathrm{kHz}$ subbottom profiler data was used (Fohrmann 1996). The domain reaches from $74^{\circ} 13^{\prime} \mathrm{N}$ to $75^{\circ} 42^{\prime} \mathrm{N}, 9^{\circ} 27^{\prime} \mathrm{E}$ to $19^{\circ} 18^{\prime} \mathrm{E}$. The interpolated Cartesian grid has a resolution of $250 \mathrm{~m}$ and covers a total area with zonal extension of $290 \mathrm{~km}$ and meridional of $165 \mathrm{~km}$.

Figure 13 shows the outflow of dense bottom water from the Kveitehola Valley. The submarine valley is situated on the outer shelf between the Storfjord Renna and Bear Island (Fig. 1b). Shelf bottom water flows from the shallow banks around the valley, into, and through the valley and cascades into the deep Norwegian Sea. Measurements (Blaume 1992), bathymetry, and numer- ical experiments (Fohrmann 1996) of the flow from the shallow banks to the shelf edge provided the initial conditions $\left(H=20 \mathrm{~m}, v=0.1 \mathrm{~m} \mathrm{~s}^{-1}, \Delta \rho=0.01 \mathrm{~kg} \mathrm{~m}^{-3}\right.$, $\left.C=0.03 \mathrm{~kg} \mathrm{~m}^{-3}\right)$. At the continental slope, the thickness of bottom sediments is assumed to be uniform and set to $1 \mathrm{~mm}$ for $63 \mu \mathrm{m}$ and $0.5 \mathrm{~mm}$ for $20 \mu \mathrm{m}$. In the Kveitehola Valley the thickness is set to $1 \mathrm{~mm}$ for both fractions. This unrealistic initial state is chosen to test whether the model is able to size-differentially redistribute the bottom sediments in a realistic way. The difference between layer thickness of the smaller fraction in the valley and at the slope prescribe a slightly more realistic grain size distribution, where the plume erodes. Numerical results for the outflow of the valley (Fig. 13a) show how the plume descends rapidly within the first two simulation days (velocities of up to $1 \mathrm{~m}$ $\mathrm{s}^{-1}$ ) down to more than $1800 \mathrm{~m}$. While depositing its suspended load on the continental rise, the plume slows down and starts to travel northward. After 5 days, the plume has lost most of its suspended material and nearly stopped moving (Fig. 13b). The resulting patterns of sediment distribution at the bottom in terms of grain size distribution and sediment thickness are in good agreement with the observed ones (Blaume 1992; Fohrmann 1996). Again the main force driving the plume to a depth greater than $2000 \mathrm{~m}$ is the density increase due to erosion of sediments on the upper continental slope.

The difference between the bulk density of the turbidity plume and the ambient water is always positive (Fig. 14b), but after 5 days the values are close to zero and the plume no longer moves horizontally. To prevent 


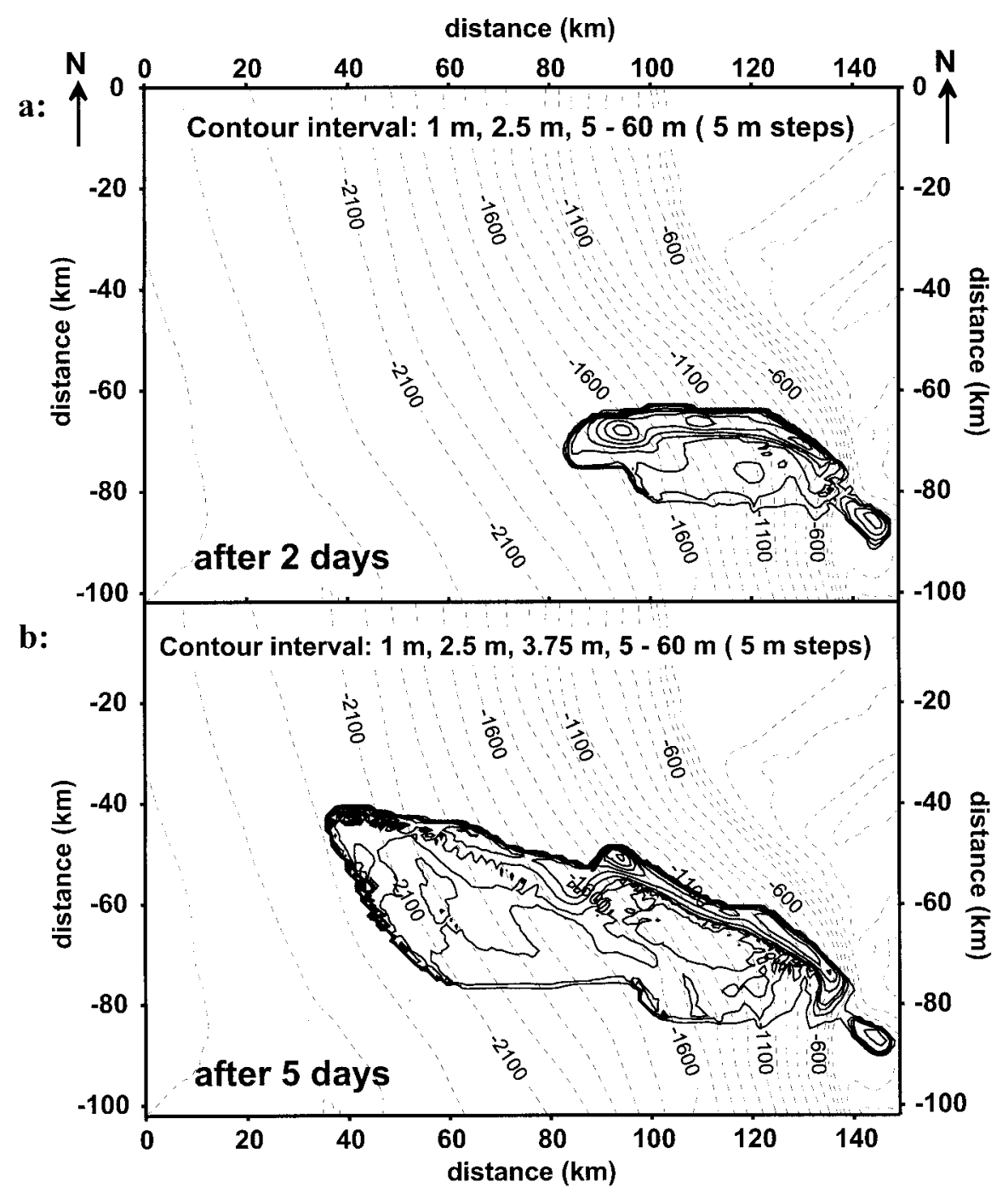

FIG. 13. Kveitehola turbidity plume outflow. The contour plots of plume height (m) at different times, after two (a) and five (b) days of simulation. The inflow is stopped after one day. Initial sediment concentration is $0.1 \mathrm{~g}^{-1}$ for each particle fraction. The regional bottom sediment availability is $1 \mathrm{~mm}$ for $20-\mu \mathrm{m}$ particles and $0.5 \mathrm{~mm}$ for $63-\mu \mathrm{m}$ particles.

a negative density contrast, the deposition term is set to zero at those grid points where the bulk density contrast is close to zero and the plume stops moving. Here the interstitial water of the plume is less dense than the ambient water, but based on the bulk density, reduced gravity remains positive. Figure 14 a shows the density contrast between the interstitial water of the plume and the ambient water. Solid contours show the part of the plume where the density contrast is still positive, forcing the plume to move slowly northward. The gray shaded area is the region of the plume where enough NAW was entrained to produce a negative density contrast. Further deposition would yield an unstable stratification, a case that cannot be simulated by this model. Such an unstable stratification, however, would be capable of initiating local upward-directed convection, lifting fine fractions from near the bottom to the overlying water. This upward convection could probably explain the often-observed BNLs extending several hundred meters above the bottom.

The regional patterns of the calculated sediment distribution at the bottom after all particles transported within the plume have been deposited (Fig. 15) represent the integrated results of erosion and deposition during the entire simulation time of the plume event (10 days). The patches, where more sediment is eroded than subsequently deposited, are shaded dark gray and indicate net erosion. The remaining patches show net deposition at the end of the simulation. The superimposed light gray region in the center of Fig. 15 indicates the observed high accumulation area (Fig. 1b), which is in good agreement with the calculated deposition area. 


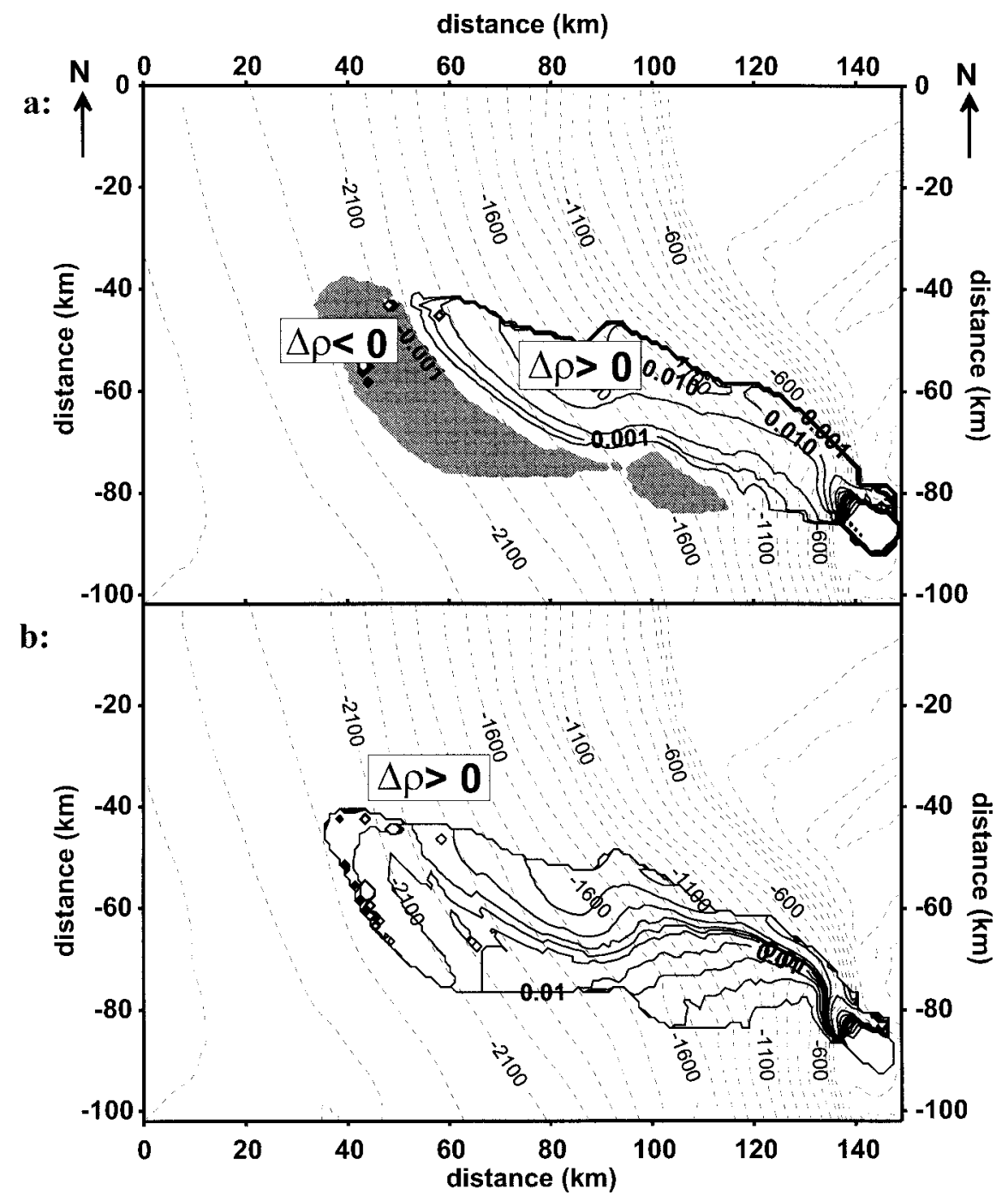

FIG. 14. Contour plots of the density difference $\Delta \rho(S, T, P)\left(\mathrm{kg} \mathrm{m}^{-3}\right)$ between density of the interstitial water of a plume and the surrounding ambient water (a). Areas with solid lines have positive values, whereas the gray shaded areas have negative values. Density difference $\Delta \rho(S, T, P$, C) $\left(\mathrm{kg} \mathrm{m}^{-3}\right)$ between bulk density and ambient water density (b).

With an inflow duration of 1 day (Fig. 15a) the main deposition area is within the high accumulation area or at greater water depth. A second experiment, with half a day of inflow and retained inflow conditions (Fig. $15 \mathrm{~b}$ ), produces a deposition area completely within the high accumulation area. This result suggests that the typical duration of a plume event is closer to one-half day than to one day. Erosion within the high accumulation area can be traced in both experiments. This indicates that the sediments at the bottom in the high accumulation area can be redistributed during a plume event and that such areas are sites of both import and export of sediments.

The calculated relative grain size distribution of the sediment at the bottom is compared to observed values (J. Rumohr 1996, personal communication) from 11 sediment cores (Fig. 16). The cores are taken on a transect from the inner Kveitehola Valley ( $\mathrm{km} \mathrm{220-150)} \mathrm{in}$ the east, across the shelf edge and the slope (km 15050), to the deep Norwegian Sea in the west (km 50-0). Symbols indicate the relative portions of the grain size $>20 \mu \mathrm{m}$ (dots) and $<20 \mu \mathrm{m}$ (triangles) observed on the sediment surface. In the Kveitehola Valley, where particles $>20 \mu \mathrm{m}$ dominate, a decreasing portion of smaller particles can be found from the inner valley to the shelf edge. The calculated values (lines) show the same general distribution pattern. Coarse silt particles (63 $\mu \mathrm{m}$ : dashed) comprise up to $100 \%$ of the sediment at the outer part, where the flow is too fast to deposit the medium silt $(20 \mu \mathrm{m}$ : solid).

In the inner valley, the portion of finer particles increases and has maximum values at the end of the valley, 


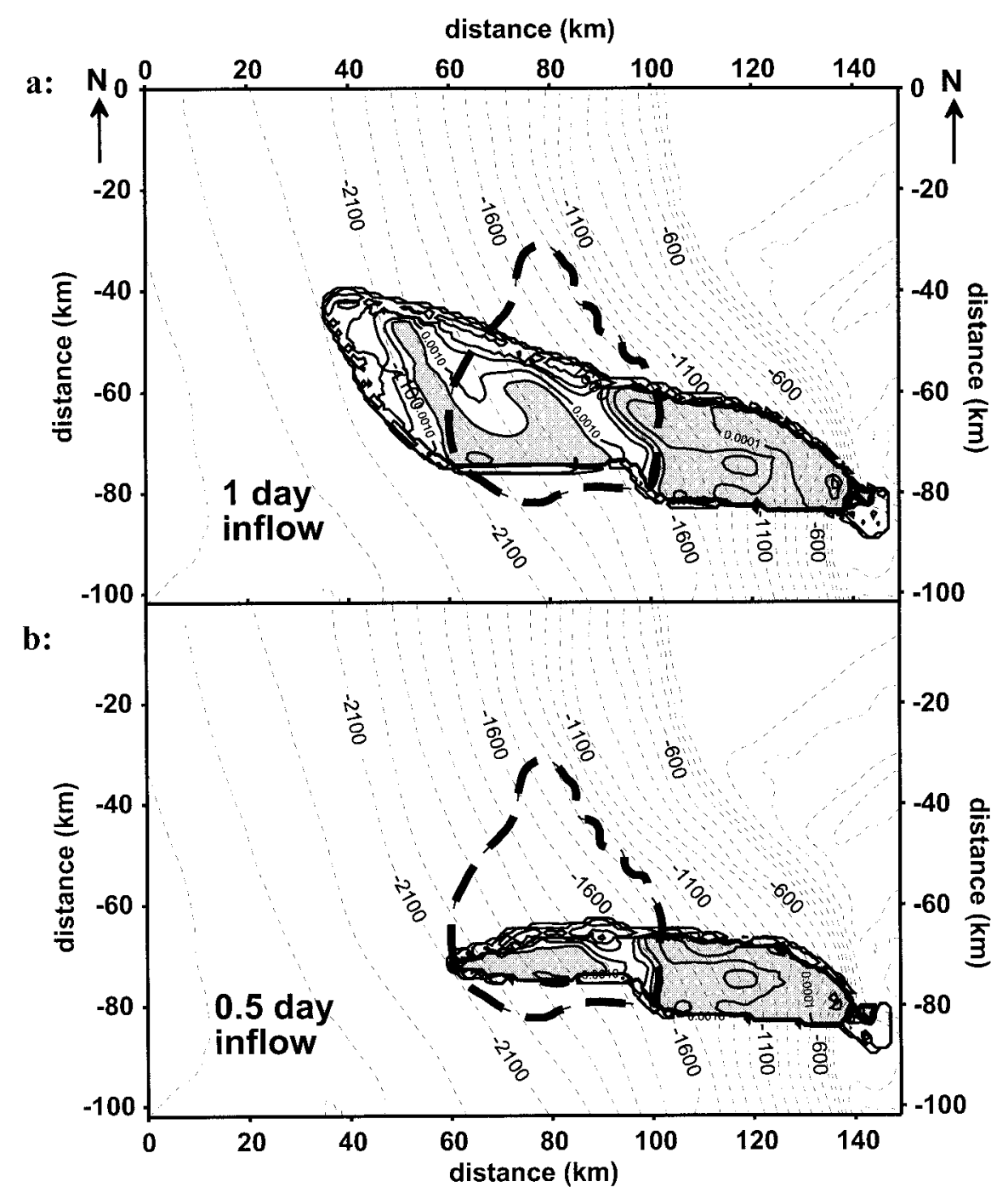

FIG. 15. Calculated bottom sediment distribution after all particles are deposited. Areas of net erosion are shown with solid lines and shaded gray, whereas areas with deposition are shown with solid lines only. Superimposed is the high accumulation area (Blaume 1992). Inflow duration is 1 day (a) and 0.5 days (b).

and in front of a sill, which crosses the valley and slows down the plume. At the base of the continental slope and in the Norwegian Sea the grain size distribution is dominated by medium silt and clay (about $80 \%<20$ $\mu \mathrm{m})$ with only $20 \%$ coarse silt. In the center of the accumulation area the finer particles $(<20 \mu \mathrm{m})$ reach maximal values of about $90 \%$. The calculated and observed distributions are in good agreement in the Kveitehola Valley and at the continental rise. The model is able to reproduce more realistic distributions of the sediment size fractions. The disagreement between observed and computed grain size distribution on the upper slope may be due to additional sediment erosion due to internal waves (Thorpe and White 1988; Fahrbach and Meincke 1982; Huthnance 1995).

\section{Are turbidity plumes important for deep-water production?}

With the extent of the high accumulation area of 1260 $\mathrm{km}^{2}$ and a mean layer thickness of $1.5 \mathrm{~m}$, the volume of younger Holocene sediments can be calculated at 1.88 $\mathrm{km} .{ }^{3}$ This, multiplied by the wet weight before drying $\left(1400 \mathrm{~kg} \mathrm{~m}^{-3}\right)$, yields $2.64 \times 10^{9} \mathrm{t}$ as the total mass of sediments in the high accumulation area. With the stratigraphically determined age (8000 yr) of the sediment the deposition rate per year can be calculated to 330000 $\mathrm{t} \mathrm{a}^{-1}$. Assuming that all this sediment was transported through the Kveitehola Valley, its outflow can be estimated. Based on bathymetry, hydrographic measurements, and simulation the width of the outflow can be 


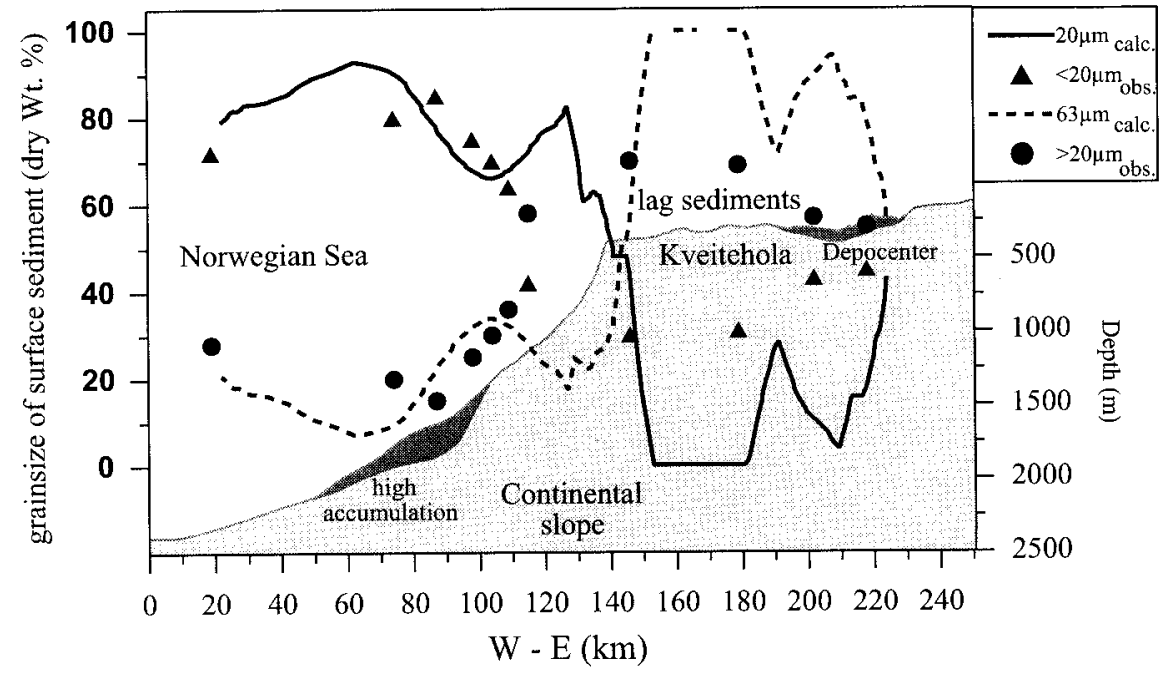

FIG. 16. Relative grain size distribution of sediment at the bottom on a transect from the Kveitehola Valley to the open ocean. Calculated values (lines) are compared to observed values (symbols). The solid line and triangles indicate the portion of particles less than/equal to $20 \mu \mathrm{m}$ and the dashed line and dots the portion of particles greater than/equal to $63 \mu \mathrm{m}$. Lag sediments are areas of partial sediment removal.

estimated at $5 \mathrm{~km}$, the height at $20 \mathrm{~m}$, and the flow velocity during an outflow event to be in the order of $0.15 \mathrm{~m} \mathrm{~s}^{-1}$. This yields an instantaneous water transport of $15000 \mathrm{~m}^{3} \mathrm{~s}^{-1}$ through the indicated cross-sectional area. To estimate the outflow duration, the transported water volume is required. Assuming a mean particle concentration of $0.1 \mathrm{~g} \mathrm{l}^{-1}$ and invoking the annual deposition rate, we arrive at a total water volume of 3.3 $\times 10^{9} \mathrm{~m}^{3} \mathrm{a}^{-1}$. If this number is divided by the instantaneous Kveitehola outflow, we arrive at an estimated mean outflow duration of 2.5 days $\mathrm{yr}^{-1}$. From the numerical results (Fig. 15) five events lasting half a day seem to be more probable than a single event lasting 2.5 days. The deep-water production due to the Kveitehola with an entrainment rate of $80 \%$, which, due to the more energetic behavior, is two times the entrainment of the Storfjord Outflow (chapter 4a; Jungclaus et al. 1995), can be calculated at $0.001 \mathrm{~Sv}\left(\mathrm{~Sv} \equiv 10^{6} \mathrm{~m}^{3}\right.$ $\mathrm{s}^{-1}$ ). This is a small value compared to the open ocean convection in the Greenland Sea $(0.5 \mathrm{~Sv})$, to the near boundary convection of the Arctic Ocean $(0.5 \mathrm{~Sv}$; Rudels and Quadfasel 1991) or to the Svalbard Outflow (0.22 Sv; Jungclaus et al. 1995).

But we note that the Kveitehola outflow is only one small site of production. Roughly estimated, the potential production area of turbidity plumes from the Barents Sea and the other shelves in the Arctic Ocean is more than one hundred times larger than the Kveitehola area and, including river and glacial input, could be larger still. Thus the potential capacity to produce deep water by turbidity plumes can be estimated to greater than 0.1 $\mathrm{Sv}$ and might be on the order of magnitude of the other convection processes.

\section{Conclusions}

Particle-enriched turbid water is more dense than particle-free water. Even with low particle concentrations the excess density due to suspended particles is comparable to the density increase of cold and saline TS plumes, caused by cooling and brine release during freezing. Since the density contrast is essentially caused by suspended matter, temperature, and salinity changes are not necessarily required to attain negative buoyancy. Storms and internal waves can cause erosion of sediment at the bottom and thus trigger turbidity plumes. In contrast to TS plumes, which are produced mainly in winter and at higher latitudes, turbidity plumes can easily be produced in all seasons and also at lower latitudes. The driving force for turbidity plumes is limited to the availability of resuspendable sediment at the bottom. Turbidity plumes are a recurring process only in the presence of a renewable particulate source. This can occur during glacial or fluvial sediment discharge and by sediment transport in sea ice. On geological timescales the availability of sediment at the bottom is increased by rising or sinking sea levels. Hence turbidity plumes may have been an important deep-water formation mechanism in earlier climate periods and can be significant during future sea level changes.

Particle-enriched turbidity plumes are able to inject shelf water masses directly into the abyssal ocean. They descend much deeper and faster into the deep basins than cold, saline TS plumes. They can penetrate strong and pronounced thermo- or haloclines, at which a $T S$ plume may be forced to intrude into the ambient water. By carrying and modifying $T-S$ characteristics they can produce distinct deep-water masses. 
The density of the interstitial fluid of a turbidity plume can become less than the density of the ambient deep water. The settling of particles can thus generate a buoyant plume, which will subsequently rise, perhaps causing upward transport of particles and water masses. The resulting destabilization of the water column serves additionally to precondition deep and intermediate waters to allow open ocean deep convection.

Finally, deep convection by turbidity plumes is an important process leading to oxygenation and nutrient supply for deep-sea environments.

Acknowledgments. We thank our colleagues at the Sonderforschnugsbereich 313, especially Stephane Pesant, Will Ritzrau, Avan Antia, and Rolf Peinert, for their help and fruitful discussions while writing this paper, and special thanks to Tom McClimans, who has done a very detailed and useful review of an earlier version. Critical comments of the anonymous reviewers are gratefully acknowledged. Christine Voigt and Maren Hein are thanked for the particle size analysis in the laboratory. This work was funded by the Deutsche Forschungsgemeinschaft DFG as part of the project SFB 313 "Veränderungen der Umwelt: Der nördliche Nordatlantik," University of Kiel.

\section{APPENDIX}

\section{Symbols}

$\begin{array}{ll}\alpha & \text { slope } \\ \eta & \text { kinematic viscosity } \\ \nu & \text { dynamic viscosity } \\ \zeta & \text { depth of interface between plume and am- } \\ & \text { bient water } \\ \sigma & \text { particle density } \\ \tau & \text { bottom stress } \\ \rho, \rho & \text { density, averaged density } \\ \rho_{w, m} & \text { density of water (particle excluded), of } \\ A_{H} & \text { suspension (particle included) } \\ B & \text { exchange coefficient } \\ C, C_{\max } & \text { Burger number } \\ & \text { particle concentration-maximum parti- } \\ D & \text { cle concentration } \\ D_{i} & \text { water depth } \\ d_{i} & \text { deposition rate } \\ \text { Ek } & \text { particle diameter } \\ E_{i} & \text { Ekman number } \\ f & \text { erosion rate } \\ g & \text { Coriolis parameter } \\ g^{\prime} & \text { gravity } \\ H & \text { reduced gravity } \\ H^{*} & \text { plume thickness } \\ \text { Index } a & \text { settling distance } \\ \text { Index } i & \text { indicates ambient properties } \\ \text { Index Pl } & \text { ndicates particle size fraction } \\ \text { Index } * & \text { Indicates properties in the plume } \\ & \text { Indicates critical properties } \\ & \end{array}$

$\mathrm{Ri}$

Ro

$r_{\text {bot,int }}$

$S$

$S_{m}$

$S_{\text {bottom }}$

$T$

$t$

V

$U, V(\bar{U}, \bar{V})$ Transport components (averaged)

$\mathbf{v} \quad$ Velocity vector

$u, v(\bar{u}, \bar{v}) \quad$ Velocity components (averaged)

$w_{e} \quad$ Entrainment velocity

$w_{s i} \quad$ Settling velocity

$x, y, z \quad$ Coordinates

\section{REFERENCES}

Aagaard, K., 1989: A synthesis of the Arctic Ocean circulation. Rapp. P.-v. Réun. Cons. Int. Explor. Mer., 188, 11-22.

— , and E. C. Carmack, 1994: The Arctic Ocean and climate: A perspective. The Polar Oceans and Their Role in Shaping the Global Environment, Geophys. Monogr., No. 85, Amer. Geophys. Union, 5-20.

- J. H. Swift, and E. C. Carmack, 1985: Thermohaline circulation in the arctic Mediterranean seas. J. Geophys. Res., 90 (C3), 4833-4846.

Adams, C. E., 1981: Some effects of suspended sediment stratification on an oceanic bottom boundary layer. J. Geophys. Res., 86 (C5), 4161-4172.

Alabyan, A. M., R. S. Chalov, V. N. Korotev, A. Y. Sidorchuk, and A. A. Zaitsev, 1995: Natural and technogenic water and sediment supply to the Laptev Sea (in Russian). German Cooperation: Laptev Sea System, H. Kassens, D. Piepenburg, J. Thiede, L. Timokhov, H.-W. Hubberten, and S. M. Primaikov, Eds., Berichte Polarforschung, 265-271.

Allen, J. R. L., 1994: Fundamental properties of fluids and their relation to sediment transport processes. Sediment Transport and Depositional Processes, S. J. Pye, Ed., Blackwell Science, 2560.

Ariathurai, R., and R. B. Krone, 1976: Mathematical modeling of sediment transport in estuaries. Estuarine Processes. Vol. 2, Circulation, Sediments, and Transfer of Material in the Estuary, M. Wiley, Ed., Academic Press, 98-106.

Blaume, F., 1992: Hochakkumulationsgebiet am Norwegischen Kontinentalhang: Sedimentologische Abbilder Topographie-geführter Strömungsmuster. Report of the Sonderforschungsbereich 313 at University Kiel, No. 36, 170 pp. [Available from Universität Kiel, Library Heinrich-Hecht-Platz 10, D-24118 Kiel, Germany.]

Blindheim, J., 1989: Cascading of Barents Sea bottom water into the Norwegian Sea. Rapp. P.-v. Réun. Cons. Int. Explor. Mer., 188, $49-58$.

Bonnecaze, R. T., H. E. Huppert, and J. R. Lister, 1993: Particledriven gravity currents. J. Fluid Mech., 250, 339-369.

— M. A. Hallworth, H. E. Huppert, and J. R. Lister, 1995: Axissymmetric particle-driven gravity currents. J. Fluid Mech., 294, 93-121.

Bouma, A. H., 1962: Methods for the Study of Sedimentary Structure Research. John Wiley, $458 \mathrm{pp}$.

Brauns, R., and K. F. Chudoba, 1964: Spezielle mineralogie. Sammlung Göschen, W.d.G. and Co., 193 pp.

Carey, S. N., H. Sigurdsson, and R. S. J. Sparks, 1988: Experimental 
studies of particle-laden plumes. J. Geophys. Res., 93 (B12), 15 314-15 328.

Dade, W. B., and H. E. Huppert, 1995a: A box model for non-entraining, suspension-driven gravity surges on horizontal surfaces. Sedimentology, 42, 453-471.

— and - 1995b: Runout and fine-sediment deposits of axissymmetric turbidity currents. J. Geophys. Res., 100 (C9), 18 597-18 609.

Einsele, G., 1992: Sedimentary Basins: Evolution, Facies and Sediment Budgets. Springer-Verlag, 628 pp.

Eisma, D., 1986: Flocculation and de-flocculation of suspended matter in estuaries. Neth. J. Sea Res., 20, 183-199.

Fahrbach, E., and J. Meincke, 1982: High-frequency velocity fluctuations on a steep continental slope. Rapp. P.-v. Réun. Cons. Int. Explor. Mer, 180, 76-77.

Fohrmann, H., 1993: Modelluntersuchung von gravity plumes auf einem topographisch gegliederten Kontinentalabhang. M.S. thesis, Oceanography Department, University of Hamburg, 83 pp.

- 1995: The influence of sediment on bottom arrested gravity plumes-Numerical case studies. Extended Abstracts, "Nordic Seas" Symp. on the Results from the Greenland Sea Project (GSP), Hamburg, Germany, 65-68.

_ 1996: Sedimente in bodengebundenen Dichteströmungen-Numerische Fallstudien. Report of the Sonderforschungsbereich 313, No. 66, University of Kiel, 106 pp. [Available from Universität Hamburg, Library, Heinrich-Hecht-Platz 10, D-24118 Kiel, Germany.]

Garcia, M., and G. Parker, 1993: Experiments on the entrainment of sediment into suspension by a dense bottom current. J. Geophys. Res., 98 (C3), 4793-4807.

Garfield, N., T. A. Rago, K. J. Schnebele, and C. A. Collins, 1994. Evidence of a turbidity current in Monterey Submarine Canyon associated with the 1989 Loma Prieta earthquake. Contin. Shelf Res., 14, 673-686.

Gascard, J.-C., 1991: Open ocean convection and deep water formation revisited in the Mediterranean, Labrador, Greenland and Weddell Seas. Deep Convection and Deep Water Formation in the Oceans, P. C. Chu and J.-C. Gascard, Eds., Elsevier, 157181.

Gibbs, R. J., and L. Konwar, 1986: Coagulation and settling of Amazon River suspended sediment. Contin. Shelf Res., 6, 127-149.

Heezen, H. W., and M. Ewing, 1952: Turbidity currents and submarine slumps and the Grand Banks earthquake. Amer. J. Sci., 250, 849-873.

Huthnance, J. M., 1995: Circulation, exchange and water masses at the ocean margin: The role of physical processes at the shelf edge. Progress in Oceanography, Vol. 35, Pergamon, 353-431.

Johnson, L. R., 1983: The transport mechanisms of clay and fine silt in the North Irish Sea. Mar. Geol., 52, M33-M41.

Jones, E. P., B. Rudels, and L. G. Anderson, 1995: Deep waters of the Arctic Ocean: Origins and circulation. Deep-Sea Res., 42, $737-760$

Jumars, P. A., J. W. Deming, P. S. Hill, L. Karp-Boss, and P. L. Yager, 1993: Physical constraints on marine osmotrophy in an optimal foraging context. Marine Microbial Food Webs, 7, 121-159.

Jungclaus, J. H., 1994: Ein numerisches Modell zur Simulation dichter Bodenströmungen im Ozean mit Anwendung auf den "Overflow" durch die Dänemarkstraße. Report of the Centre of Marine and Climate Research at the University Hamburg, No. 10, 122 pp. [Available from Institut für Meereskunde, TroplowitzstraBe 7, D-22529 Hamburg, Germany.]

_ , and J. O. Backhaus, 1994: Application of a transient reduced gravity plume model to the Denmark Strait Overflow. J. Geophys. Res., 99 (C6), 12 375-12 396.

- - - and H. Fohrmann, 1995: Outflow of dense water from the Storfjord in Svalbard: A numerical model study. J. Geophys. Res., 100 (C12), 24 719-24 728.

Kerr, R. C., 1991: Erosion of a stable density gradient by sedimentation-driven convection. Nature, 353, 423-425.
Killworth, P. D., 1983: Deep convection in the world ocean. Rev. Geophys. Space Phys., 21, 1-26.

Laval, A., M. Cremer, P. Beghin, and C. Ravenne, 1988: Density surges: Two-dimensional experiments. Sedimentology, 35, 7384.

Martin, D., and R. Nokes, 1988: Crystal settling in a vigorously convecting magma chamber. Nature, 332, 534-536.

McCave, I. N., 1984: Size spectra and aggregation of suspended particles in the deep ocean. Deep-Sea Res., 31, 329-352.

Mellor, G. L., and P. A. Durbin, 1975: The structure and dynamics of the ocean surface mixed layers. J. Phys. Oceanogr., 5, 718728.

Menard, H. W., 1964: Marine Geology of the Pacific. McGraw-Hill, $271 \mathrm{pp}$.

Norsk Polarinstitutt, 1989: Western Barents Sea bathymetry: A seafloor map compiled by Y. Kristofferson, M. Sand, B. Beskow, and Y. Ohta in 1988. Norsk Polarinstitutt Skrifter, Y. Kristofferson, M. Sand, B. Beskow, and Y. Ohta, Eds., Norsk Polarinstitutt.

Odd, N. V. M., 1988: Mathematical modelling of mud transport in estuaries. Physical Processes in Estuaries, J. Dronkers and W. v. Leussen, Eds., Springer-Verlag, 503-531.

Paetsch, H., 1992: Accumulation rates of surface sediments in the Norwegian-Greenland Sea. Mar. Geology, 104, 19-30.

Pantin, H. M., 1991: A model for ignitive autosuspension in brakish underflows. Euromech 262-Sand Transport in Rivers, Estuaries and the Sea. S. Bettess, Rotterdam, 283-291.

Parker, G., Y. Fukushima, and H. M. Pantin, 1986: Self-accelerating turbidity currents. J. Fluid Mech., 171, 145-181.

Parker, W. R., 1984: On the observation of cohesive sediment behaviour for engineering purposes. Workshop on Cohesive Sediment Dynamics with Special Reference to Physical Processes in Estuaries, A. J. Mehta, Ed., Springer-Verlag, 270-289.

Pfirman, S. L., and A. Solheim, 1989: Subglacial meltwater discharge in the open-marine tidewater glacier environment: Observations from Nordaustlandet, Svalbard archipelago. Mar. Geol., 86, 265281.

Prandtl, L., K. Oswatitsch, and K. Wieghardt, 1990: Führer durch die Strömungslehre. Vieweg, $648 \mathrm{pp}$.

Quadfasel, D., B. Rudels, and K. Kurz, 1988: Outflow of dense water from a Svalbard fjord into the Fram Strait. Deep-Sea Res., 35, $1143-1150$.

- , H. Kudrass, and A. Frische, 1990: Deep-water renewal by turbidity currents in the Sulu Sea. Nature, 348, 320-322.

Ritzrau, W., and G. Graf, 1992: Increase of microbial biomass in the benthic turbidity zone of Kiel Bight after resuspension by a storm event. Limnol. Oceanogr., 37, 1081-1086.

- , and H. Fohrmann, 1998: Field and numerical studies of near bed particle dynamics. Int. Symp. on Computerized Modeling of Sedimentary Systems, J. Harff and K. Stattegger, Eds. SpringerVerlag, in press.

Rudels, B., and D. Quadfasel, 1991: Convection and deep water formation in the Arctic Ocean-Greenland Sea System. J. Mar. Syst., 2, 435-450.

Rumohr, J., and F. Blaume, 1996: Bericht über die 181 Fahrt des Forschungsschiffes Poseidon ins nördliche europäische Nordmeer. Report of the Sonderforschungsbereich 313, No. 63, 6490. [Available from Universität Kiel, Library, Heinrich-HechtPlatz 10, D-24118 Kiel, Germany.]

Schauer, U., 1995: The release of brine-enriched shelf water from Storfjord into the Norwegian Sea. J. Geophys. Res., 100 (C8), $16015-16028$.

Schlosser, P., J. H. Swift, D. Lewis, and S. Pfirman, 1995: The role of the large-scale Arctic Ocean circulation in the transport of contaminants. Deep-Sea Res., 42, 1341-1367.

Sheng, P. Y., and C. Villaret, 1989: Modeling the effect of suspended sediment stratification on bottom exchange processes. J. Geophys. Res., 94 (C10), 14 429-14 444.

Sparks, R. S. J., R. T. Bonnecaze, H. E. Huppert, J. R. Lister, M. A. Hallworth, H. Mader, and J. Phillips, 1993: Sediment-laden grav- 
ity currents with reversing buoyancy. Earth Planet. Sci. Lett. 114, 243-257.

Stow, D. A. V., 1994: Deep sea processes of sediment transport and deposition. Sediment Transport and Depositional Processes, K. Pye, Ed., Blackwell Science, 257-291.

- , and A. J. Bowen, 1980: A physical model for the transport and sorting of fine-grained sediment by turbidity currents. Sediment. Geol., 27, 31-46.

grained turbidities: Comparison of recent deep-sea and ancient flysch sediments. Sediment. Geol., 25, 23-47.

Thomsen, L., 1993: Untersuchungen zur Bodennepheloidschicht am westlichen Barents See Kontinentalhang. Report of the Sonderforschungsbereich 313 at University Kiel, No. 39, 95 pp. [Available from Universität Kiel, Library, Heinrich-Hecht-Platz 10, D24118 Kiel, Germany.]

Thorpe, S. A. and M. White, 1988: A deep intermediate nepheloid layer. Deep-Sea Res., 35, 1665-1671.

Turner, J. S., 1973: Buoyancy Effects in Fluids. Cambridge University Press, $367 \mathrm{pp}$.

UNESCO, 1981: Tenth report of the joint panel on oceanographic tables and standards. UNESCO Tech. Papers to Marine Sciences $36,25 \mathrm{pp}$.

Unsöld, G., 1984: Der Transportbeginn feinstkörnigen rolligen Sohlmaterials in gleichförmigen turbulenten Strömungen: Eine experimentelle Überprüfung und Erweiterung der SHIELDS-Funktion. Report of the Sonderforschungsbereich 95 at the University Kiel, No. 70, 141 pp. [Available from Universität Kiel, Library, Westring 400, D-24118 Kiel, Germany.]

Vogelsang, E., 1990: Paläo-Ozeanographie des Europäischen Nordmeeres an Hand stabiler Kohlenstoff- und Sauerstoffisotope. Report of the Sonderforschungsbereich 313 at the University of Kiel, No. 23, 136 pp. [Available from Universität Kiel, Library, Westring 400, D-24118 Kiel, Germany.]

Wollenburg, I., 1993: Sediment transport by Arctic Sea Ice: The recent load of lithogenic and biogenic material. Rep. on Polar Research AWI, No. 127, 159 pp. [Available from Alfred Wegener Institute for Polar and Marine Research, Columbusstraße, D2850 Bremerhaven, Germany.]

Zeng, J., and D. R. Lowe, 1997: Numerical simulation of turbidity current flow and sedimentation: I. Theory. Sedimentology, 44, 67-84. 